\title{
A corpus-aided discovery learning (CADL) approach to teaching collocations in TEFL settings
}

\author{
Dr Wesam M. A. Ibrahim* Dr Amany A. Alsabbagh ** \\ * Associate Professor of Linguistics \\ Department of Foreign Languages, Faculty of Education, Tanta \\ University, Egypt \\ Department of Basic Sciences, Community College, Princess Nourah \\ bint Abdulrahman University, Saudi Arabia \\ ** TEFL Associate Professor, Head of English Language and \\ Computer Science Department, Police Science Academy, \\ Sharjah, UAE
}

\begin{abstract}
:
Despite the progress made in the field of corpus linguistics, the use of corpora is relatively scarce in language pedagogy (Krieger, 2003). However, the effectiveness of using corpus-based activities in teaching English has been supported by researchers (Vannestal and Lindquist, 2007). This paper discusses the potential of using a corpus-aided discovery learning (CADL) approach in TEFL settings, particularly in teaching collocations (i.e. habitual cooccurrences of lexical items). There is consensus that the study of collocations is vital for developing language skills and fostering fluency and accuracy (e.g. Biber et al.,1999; McEnery \& Wilson, 2001; McAlpine \& Myles, 2003) since competence in a language undoubtedly involves collocational knowledge (Herbst, 1996: 389). Evidently, learners' knowledge of collocations is quite important (Kita and Ogata, 1997: 230) and is needed for effective sentence generation (Smadja and McKeown, 1990) and avoidance of errors (McAlpine and Myles, 2003: 75). In this paper, we argue that using a CADL approach and involving learners in corpus-based activities in the study of collocations would extend their lexicon. To support this argument, the researchers initiated an experiment applying a CADL approach to the teaching of vocabulary, particularly
\end{abstract}


(ISSN : 2536 - 9555)

collocations, in the Faculty of Education, Tanta University, Egypt. 20 third-year students were introduced to the $\mathrm{BNC}^{1}$ web and were given a hands-on session on how to use the BNC. Then, learners were asked to look at the concordances of the most frequent 10 nouns in the BNC, namely: 'time', 'people', 'way', 'years', 'year', 'work', 'government', 'day', 'man', and 'world'; to decide which adjectives most frequently occur with these nouns; to extract collocates for each noun; and to discuss their findings with their colleagues. This is followed by a number of exercises in which students use the collocates they have found. The aim of the study, or as Chambers (2007) and Mukherjee (2004) call it 'task', is to 'popularise' the work with corpus data in TEFL settings. Hence, language learners would not rely solely on the teacher but would deal with corpora on their own under the teacher's guidance and find out about language patterning and the behaviour of words and phrases in an 'autonomous' way (Bernardini, 2002: 165).

\section{Keywords}

Corpus Linguistics, Collocation, Vocabulary teaching, corpusaided discovery learning (CADL)

${ }^{1}$ The British National Corpus (BNC) was originally created by Oxford University press in the 1980s - early 1990s, and it contains 100 million words of text texts from a wide range of genres (e.g. spoken, fiction, magazines, newspapers, and academic).

https://www.english-corpora.org/bnc/ 
A corpus-aided discovery learning (CADL) approach to teaching collocations in TEFL settings

Dr Wesam M. A. Ibrahim \& Dr Amany A. Alsabbagh

مجلة وادي النيل للاراسات والبحوث الإنسانية والاجتماعية والتربوية (مجلة علمية محكمة)

استخام التعلم الاستكثافي المدعوم بالمخزونات اللغوية في تدريس المتلازمات اللفظية في نطاق تدريس اللفة الانجليزية كلغة أجنبية

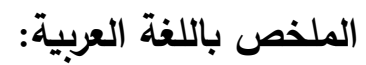

يعد استخدام المخزونات اللغوية في تدريس اللغات أمرًا نادرًا رغم التقدم

الكبير الذي احرزه علم المخزونات اللغوية. ومع هذا، فإن كثير من الباحثين أكدوا

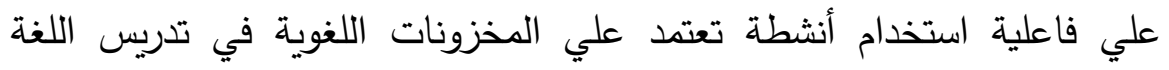

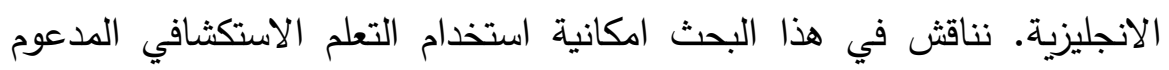

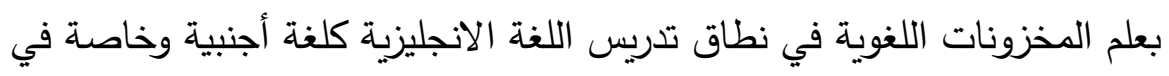

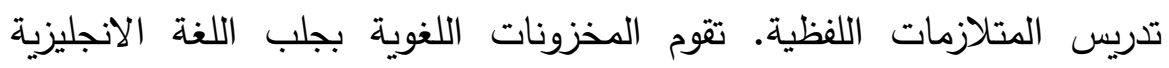
الواقعية الي الفصل الدراسي وفي نفس الوقت تدعم التعلم المستقل. يوجد إتفاق بين العلماء علي أهمية دراسة المتلازمات اللفظية في تطوير مهارات اللغة وإثراء الطلاقة والدقة اللغوية. يحتاج الطلاب أن يتعلمون المتلازمات اللفظية لانتاج

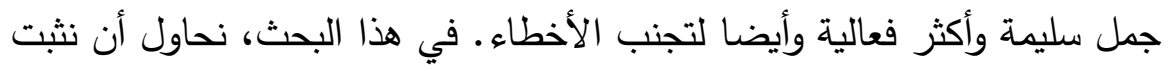

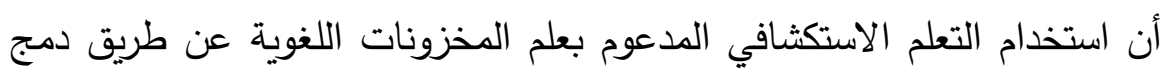
الطلاب في أنشطة تعتمد علي المخزونات اللغوية سوف يؤدي الي زيادة ثروتهم

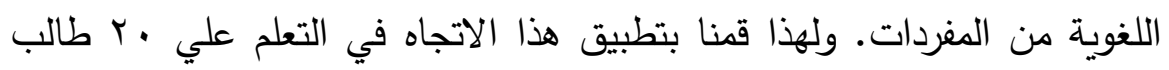

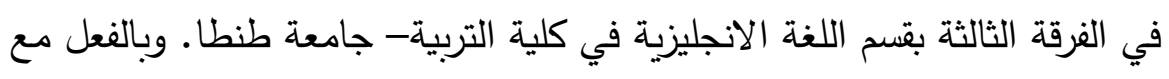
نهاية الفصل الدراسي اندمج الطلاب في الانشطة واكتسبوا العديد من المتلازمات اللفظية ومن ثم تم اثراء مفرداتهم اللغوية.

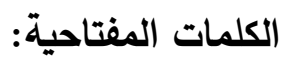

علم الدخزونات اللغوية، المتلازمات اللفظية، تدريس المفردات، التعلم الاستكثافي المدعوم بالمخزونات اللغوية.

815 ) 
مجلة وادي النيل للاراسات والبحوث الإنسانية والاجتماعية والتربوية (مجلة علمية محكمة)

(ISSN : 2536 - 9555)

\section{Introduction}

Corpora can have a huge impact on language teaching due to its ability to present statistically proven evidence of language use. Hence, there is a growing tendency to incorporate corpora in language teaching (Johansson, 2009; Leńko-Szymańska, 2014). From this perspective, this paper explores the potential of using corpus-based activities in TEFL settings, particularly in the study of English vocabulary (Johns, 1991a; Leech, 1997; Carter, 1998). Indeed, the ultimate aim of this paper is to highlight the pedagogical usefulness of corpora for vocabulary teaching and learning, and for developing in students some basic lifelong learning skills (European Framework for Key Competences 2018²).

\section{Corpus Linguistics}

A corpus can be defined as a large collection of machinereadable, authentic written and/or spoken texts that acts as a representative sample of a particular language or variety of language (McEnery, Xiao and Tono, 2006). Corpus linguistics, considered as a 'new enterprise' or way of thinking about language, can be used as a tool to carry out empirical studies on language. It provides a perspective on natural occurring language that sets it apart from intuition-based approaches which rely on the overt judgement of an individual about the language (Leech, 1992; Conrad, 2000; Teubert, 2005).

In recent years, Corpus Linguistics has begun to play a chief role in various areas such as discourse analysis (Ibrahim, 2014b; Krishnamurthy, 1996; Teubert, 2007), translation studies (Bassnett, 2002; Laviosa, 2002), sociolinguistics (Baker, 2010) and stylistics (Ibrahim, 2013, 2014a; Semino and Short, 2004; Wynne, 2005). Corpora provides researchers an access to 'real world' texts and corpus-based analysis which facilitates naturalistic linguistic

\footnotetext{
${ }^{2} \mathrm{https} / /$ eur-lex.europa.eu/legalcontent/EN/TXT/PDF/?uri=CELEX:52018SC0014\&from=EN
} 
A corpus-aided discovery learning (CADL) approach to teaching collocations in TEFL settings

Dr Wesam M. A. Ibrahim \& Dr Amany A. Alsabbagh

$$
\text { مجلة وادي النيل للاراسات والبحوث الإنسانية والاجتماعية والتربوية (مجلة علمية محكمة) }
$$

investigation. Corpus analysis software and machine-readable corpora make it possible for researchers to investigate huge amounts of data at a significantly lesser time with the highest degree of accuracy.

The term 'corpus', which is originally a Latin word meaning 'a body', is a collection of texts (a 'body' of language) stored in an electronic database. Corpus Linguistics is mainly concerned with studying how language (spoken or written or both) is used in natural occurring settings such as everyday conversations, newspapers, online communications, spontaneous telephone conversations ... etc (Adolphs and Lin, 2011: 597). It is the study of language based on examples of authentic language use, collected, stored and processed via a computer. It can be defined as "a collection of texts assumed to be representative of a given language, dialect, or other subset of a language" (Francis, 1982: 7); "an unexciting phenomenon, a helluva lot of text, stored on a computer" (Leech, 1992); "a collection of naturally-occurring language text, chosen to characterize a state or a variety of language" (Sinclair, 1991); a finite-sized body of machine-readable text, sampled in order to be maximally representative of the language variety under consideration' (McEnery and Wilson, 2001: 32); "a collection of pieces of language text in electronic form, selected according to external criteria to represent, as far as possible, a language or language variety as a source of data for linguistic research" (Sinclair, 2004); and as "large bodies of machine-readable text containing thousands or millions of words" (Baker et al., 2006: 48).

Linguists tend to use a number of software packages in corpus analysis such as Mike Scott's Wordsmith Tools 5 (Scott, 2008). These software packages offer corpus analysts a wide variety of functions and enable them to investigate corpora in a more reliable way. Hunston (2002: 3) observes that 'a corpus does not contain new information about language, but the software offers us a new perspective on the familiar.' These software 
(ISSN : 2536 - 9555)

packages, which are based on the premise that corpora are sets of machine-readable texts which can be searched quickly, offer various facilities e.g. keywords, concordances, frequency lists, and collocations. This study is mainly interested in the notion of collocation.

Collocation is a highly significant technique that is used widely in corpus analysis. J. R. Firth (1957), one of the pioneers in the field of Linguistics, was the first to explore the notion of collocation, arguing that ' $[\mathrm{y}] \mathrm{g}$ shall know a word by the company it keeps' (Firth, 1957: 179), and thus inspiring corpus linguists to use this phenomenon in its full sense (McEnery \& Wilson, 2001: 23-24). Furthermore, Firth (1957: 14) suggested that pairs of words are considered collocates when they show a strong mutual attraction. Sinclair (1987c) and Stubbs (1996) suggested that all lexical items have collocations. That is why Sinclair (1987b) suggested that collocates are "words which co-occur significantly with headwords.' For example, among the verbs which may accompany the noun 'kiss' would be want, return, steal, or give. The notion of collocation was employed in designing learner dictionaries such as COBUILD (Sinclair, 1987a) and the Oxford Collocations Dictionary. Strictly speaking, there are two major factors which should be taken into account when addressing collocates in order to distinguish between chance pairings and significant collocates: (1) the circumstances under which cooccurring items are attracted and hence, they are said to be collocates, and (2) the quantitative techniques (statistical techniques) which measure the strength of attraction between collocates.

\section{Corpus Linguistics and Language Pedagogy}

The use of a corpus-based approach in language pedagogy is particularly interesting for the purposes of this paper. It should be noted that the use of corpus-based activities in pedagogical settings has gained prominence since the mid-1980s because corpus analysis can be illuminating 'in virtually all branches of linguistics 
A corpus-aided discovery learning (CADL) approach to teaching collocations in TEFL settings

Dr Wesam M. A. Ibrahim \& Dr Amany A. Alsabbagh

$$
\text { مجلة وادي النيل للاراسات والبحوث الإنسانية والاجتماعية والتربوية (مجلة علمية محكمة) }
$$

or language learning' (Leech, 1997: 9; Biber, Conrad \& Reppen, 1998: 11).

The upsurge of interest in applying the findings of corpusbased research to language pedagogy is evidenced in the amount of scholarly work and publications on the topic of teaching and language corpora. Examples include Wichmann, Fligelstone, McEnery and Knowles (1997), Partington (1998), Bernardini (2000), Burnard and McEnery (2000), Aston (2001), Ghadessy, Henry and Roseberry (2001), Granger, Hung and Petch-Tyson (2002), Hunston (2002), Kettemann and Marko (2002, 2006), Sinclair (2003, 2004), Aston, Bernardini and Stewart (2004), Mishan (2005), Nesselhauf (2005), Römer (2005), Braun, Kohn and Mukherjee (2006), Gavioli (2006), Scott and Tribble (2006), Hidalgo, O'Keeffe, McCarthy and Carter (2007), Quereda and Santana (2007), Aijmer (2009) and Campoy, Gea-valor and BellesFortuno (2010).

The interest of corpus linguists in the applications of corpus-based research in the English language classroom (Burnard and McEnery, 2000; Aston, 2001) has led to the initiation of the COBUILD project (and consequently, the production of a new generation of learner dictionaries) (Sinclair, 1987a), and the early coinage of the notion of 'data-driven learning' (Johns, 1991a). However, one must admit that the influence of applying corpuslinguistic research on English language teaching is still relatively rare and unexploited since 'not many teachers seem to be using corpora in their classrooms' (Tribble, 2000: 31).

The computer-assisted corpus-based analysis of data, especially by means of extracting wordlists, frequencies, keywords, collocations and concordances offered by corpus-linguistic software packages such as WordSmith Tools (Scott, 2008) opens up entirely new perspectives for linguistic analysis: '[t]he corpus is stored in such a way that it can be analysed non-linearly, and both quantitatively and qualitatively' (Hunston, 2002: 2). The use of corpus-based approaches in TEFL settings has the potential for two 
(ISSN : 2536 - 9555)

major effects upon the professional life of teachers of English language:

Firstly, corpora lead to new descriptions of a language, so that the content of what the language teacher is teaching is perceived to change in radical ways $[\ldots]$. Secondly, corpora themselves can be exploited to produce language teaching materials, and can form the basis for new approaches to syllabus design and to methodology. (Hunston, 2002: 137)

\section{The Contribution of Corpus Linguistics to Language Pedagogy}

Corpus linguistics is considered to be an approach to the study of language rather than a branch of linguistics (Gries, 2009). The approach, which focuses on the analysis of authentic samples of language use, has an impact on language teaching, particularly in syllabus design, teaching materials (dictionaries and books) and classroom activities (Krieger, 2003). With regard to classroom activities, its use is not widespread in EFL classes and tends to be mainly confined to a very small number of university teachers. This paper presents a corpus-based task which exploits corpora for vocabulary teaching and learning. It aims to discuss the potential of corpus work in the learning of English vocabulary as well as in the development of some of the key life-long learning skills. The corpus-based approach to learning promotes the development of some basic skills for lifelong learning (European Framework for Key Competences, 2018) by encouraging students to be active learners in the classroom and to apply their critical thinking to the study of vocabulary. In this sense, the corpus-based approach to learning vocabulary dedicates a special emphasis to two key aspects: autonomous learning (students' ability to learn independently) and the study of authentic language use (which enhances the ability and the skill to communicate in English). In 
A corpus-aided discovery learning (CADL) approach to teaching collocations in TEFL settings

Dr Wesam M. A. Ibrahim \& Dr Amany A. Alsabbagh

مجلة وادي النيل للاراسات والبحوث الإنسانية والاجتماعية والتربوية (مجلة علمية محكمة)

addition, it introduces new technologies in the classroom (thus, enhancing the students' digital competence), which matches the $21^{\text {st }}$ century spirit of digital empowerment.

The use of corpora in language teaching has many benefits including the following:

- providing learners with more accurate descriptions of language than those based on intuitions

- exposing learners to contextualized, meaningful language in 'real' usages

- providing learners with examples of specific registers/genres of language

- exposing learners to non-textbook language patterns

- giving learners access to a much larger language sample than classes can normally provide

Corpora can be used in teaching vocabulary (word meanings in context, combinations/collocations, parts of speech, common expressions, differences in meaning), grammar (differences between similar forms, how forms are used in context), pragmatics (greetings, genre features and their cultural meanings - e.g. job letters, CVs, personal letters, etc.). An example of these studies can be seen in Tsui (2005). Amy Tsui used a corpus compiled from TeleNex website 1993-2005 to support ESL teachers in Hong Kong. She dealt with lots of questions about commonly confused words, use of sentence connectives, count vs non-count nouns, number agreement, etc. Examples include: big vs large, finally vs lastly, and less than vs fewer than. She argued that accurate information about usage can be obtained from corpus data.

Acquisition of language and linguistic competence as well as language learning awareness can best be realised through tasks which encourage learners not to focus explicitly on the structure 
(ISSN : 2536 - 9555)

and the rules of the new language. Learners will acquire the form of the foreign language because they are engaged in exploring aspects of the target language on the basis of authentic content. They are involved in learner-centred activities and are motivated to exploit tools rather than ready-made learning materials. This kind of learning, which may be dubbed data-driven learning or taskbased learning, involves the use of new technology to enhance language learning, the focus on real tasks and activities, and the exploitation of authentic materials. The exploitation of corpus methods in data-driven learning or task-based learning has given rise to what is known as corpus-aided discovery learning (CADL). The CADL approach entails encouraging learners to take the role of language researchers by systematically engaging in discovery learning (Gavioli, 2000) and in learning how to learn through observations, analyses, interpretations, and presentations of language-use patterns in corpus data.

\section{Corpus-Aided Discovery Learning (CADL)}

Educators have advocated a variety of active learning approaches believing that these approaches encourage learners to be more autonomous, to discover for themselves, and to be more engaged in the educational process which would eventually have an impact on achieving the intended learning outcomes (ILOs). Examples of these active learning approaches include problembased, inquiry-based, experiential, and discovery learning. These approaches agree on using group work, hands-on experience, and social interaction to enhance students' ability to discover new concepts on their own. However, there is a debate as to the mount of guidance students need to support their efficacy, especially for novice learners (e.g., Kirschner, Sweller, and Clark, 2006). Many educators believe that effective learning requires teachers' guidance and intervention to ensure that students are kept on the task with a clear focus on the learning objectives. Hence, active learning approaches are more supported by educators when they provide an 
A corpus-aided discovery learning (CADL) approach to teaching collocations in TEFL settings

Dr Wesam M. A. Ibrahim \& Dr Amany A. Alsabbagh

$$
\text { مجلة وادي النيل للاراسات والبحوث الإنسانية والاجتماعية والتربوية (مجلة علمية محكمة) }
$$

active role for the teacher and an opportunity to intervene (Mayer, 2004). From this perspective, teachers and students share responsibility for the efficacy of the learning process and the achievement of the ILOs.

Corpus-aided discovery learning makes the most of corpora as learning aids. This approach is associated with Tim Johns and with his work on data-driven learning (DDL) (Johns, 1991b). Indeed, "the hands-on use of authentic corpus data [...] for inductive, self-directed language learning [...] empowering learners to explore language corpora and come to their own conclusions (Boulton, 2011: 571). Bernardini (2004a) argues that inductive learning from corpora is more effective than explicit instruction for the acquisition of specific language structures. She also emphasized, through the Learner as Traveler metaphor, the importance of focusing on the learning experience itself: the learner is a traveler and the focus should be on the learning experience, the voyage, rather than its destination. When guided by the teacher, corpus-aided discovery learning (CADL) in Teaching English as a Foreign Language (TEFL) settings would involve students in active learning, since this approach requires teachers to guide students in their endeavour to conduct research, discover, and reflect on various aspects of English.

This approach appears to be potentially well-suited for TEFL learners for the following reasons (Bernardini, 2016; Flowerdew, 2015). First, it is learner-centered and autonomypromoting, which is quite valuable in TEFL context particularly for learners at advanced levels (Nunan, 1988). CADL is "fully adaptable to the learner's individual needs and preferences [,] where the learner has an ability to select from an unrestrictive range of responses, or even to come up with responses not envisaged by the teacher" (Leech, 1997: 11-12). Second, CADL is an inductive process which is meant to favour the noticing of patterns (Schmidt, 2010), including collocational patternings (Sinclair,1996), and to demonstrate the effect of context of 
(ISSN : 2536 - 9555)

situation and context of culture on such patternings (Halliday and Mathiessen, 2014). Third, CADL is a form of communicative learning whereby knowledge is "co-constructed through collaborative dialogue and negotiation with guidance and support mediated by the teacher or student" (Flowerdew, 2015: 19). It is proposed by many academics that the CADL approach could indeed contribute to the development of various competences that would enhance students' capacity for lifelong learning including: thematic competence (learning to search for information), technological competence (learning to use electronic software) and information mining competence (developing strategies for extracting terminology and phraseology, evaluating sources, etc.) (EMT Expert Group, 2017; Bernardini, 2016).

\section{Methodology}

This study seeks to answer the following research question:

Would the use of corpus-aided discovery learning activities have an impact on extending the scope of students' vocabulary?

\section{Participants}

This study, an experiment involving corpus-aided discovery learning, was conducted on 20 third-year students in the Department of Foreign Languages (English Programme), Faculty of Education, Tanta University. The participants were enrolled in a course entitled 'Introduction to Linguistics', taught by the first author. The number of students enrolled for this course was about 300 students. Students were informed of the nature of the experiment and how computer software would be used as a tool to explore language patterns. Students were excited about using new methods in learning English vocabulary and were really eager to improve their English language. More than 120 students 
A corpus-aided discovery learning (CADL) approach to teaching collocations in TEFL settings

Dr Wesam M. A. Ibrahim \& Dr Amany A. Alsabbagh

مجلة وادي النيل للاراسات والبحوث الإنسانية والاجتماعية والتربوية (مجلة علمية محكمة)

volunteered for the experiment. 20 students were randomly selected from the volunteers. The group included 12 females and 8 males between 20 and 22 years old. All students have, on average, an intermediate English proficiency level, based on a paper-based placement test. The research was conducted in the first semester of the academic year 2018-2019.

\section{Instruments}

The tools which were administered to collect relevant data for this study include pre- and post- vocabulary tests. The researchers developed two equivalent forms of vocabulary tests (fill-in-the-gap activity); one was used as a pre-test and the other as a post-test. The activity included ten questions, as seen in Table 1. The participants were provided with 10 nouns (the most frequent nouns in the BNC) and were asked to fill in each blank with one or more adjectives.

1. -------- time

3. -------- way

5. -------- year

7.-------- government

9. -------- man
2. ------- people

4. -------- years

6. -------- work

8. -------- day

10. ------- world

Table 1 Pre- and post- tests: Fill-in-the-gap activity

\section{Validation of study instruments}

To verify validity and reliability of the pre- and post-tests, they were piloted on the control group $(N=20)$. Statistical analyses of Pearson Correlation coefficients rendered high equivalent 
(ISSN : 2536 - 9555)

reliability values of 0.91 . As for inter-rater reliability, two raters reached an agreement level as high as $0.98 \%$ on students' scores.

\section{Procedures of the Study}

The procedures of the study were as follows:

1. The 20 participants were asked to take part in a 'fill-in-thegap' activity in which they would provide the adjectives which (they think) tend to come with the following nouns (the most frequent 10 nouns in the BNC): 'time', 'people', 'way', 'years', 'year', 'work', 'government', 'day', 'man', and 'world'. (Pre-test)

2. The 20 participants were divided into groups of four.

3. Each group was equipped with a computer desktop with an Internet connection to work on the online corpus, the BNC.

4. The participants were introduced to the BNC web and were given a hands-on session on how to use the BNC.

5. They were asked to extract the most frequent 10 nouns in the BNC.

6. They were asked to look at the concordances of each noun.

7. They were asked to decide if there were certain adjectives which tend to occur more frequently with each noun, through examining the concordances.

8. They were introduced to the concept of collocation.

9. They were trained on how to extract collocates from the BNC.

10. Each student was asked to take part in a fill-in-the-gap activity which requires him/her to insert 5 possible collocates for each noun. (Post-test)

11. This is followed by a number of exercises.

\section{Data Analysis}

The paired samples $T$-test ${ }^{3}$ was used to identify the difference between the score of the student groups in pre- and post-

${ }^{3}$ You can compare the means of two groups with a two-sample t-test. If you have two groups with paired observations (e.g., before and after 
A corpus-aided discovery learning (CADL) approach to teaching collocations in TEFL settings

Dr Wesam M. A. Ibrahim \& Dr Amany A. Alsabbagh

$$
\text { مجلة وادي النيل للاراسات والبحوث الإنسانية والاجتماعية والتربوية (مجلة علمية محكمة) }
$$

tests (i.e., a fill-in-the-gap activity which was conducted before and after the task). The results reveal the effect of using CADL on extending the participants' scope of vocabulary, where the significance threshold was set at 0.01 . Descriptive statistics were performed to provide an overview about the students' scores in the pre- and post-tests. Relevant data to the effect of using CADL are provided in the table below.

measurements), use the paired t-test. Each type of t-test uses a specific procedure to boil all of your sample data down to one value, the t-value. The calculations behind t-values compare your sample mean(s) to the null hypothesis and incorporates both the sample size and the variability in the data. A specific t-distribution is defined by its degrees of freedom (DF), a value closely related to sample size. Therefore, different tdistributions exist for every sample size.

https://blog.minitab.com/blog/adventures-in-statistics-2/understanding-ttests-t-values-and-t-distributions

Calculating a t-test requires three key data values. They include the difference between the mean values from each data set (called the mean difference), the standard deviation of each group, and the number of data values of each group. The t-test produces two values as its output: tvalue and degrees of freedom. The t-value is a ratio of the difference between the mean of the two sample sets and the variation that exists within the sample sets. While the numerator value (the difference between the mean of the two sample sets) is straightforward to calculate, the denominator (the variation that exists within the sample sets) can become a bit complicated depending upon the type of data values involved. The denominator of the ratio is a measurement of the dispersion or variability. Higher values of the t-value, also called t-score, indicate that a large difference exists between the two sample sets. The smaller the t-value, the more similarity exists between the two sample sets. A large t-score indicates that the groups are different. A small tscore indicates that the groups are similar.

https://www.investopedia.com/terms/t/t-test.asp 
مجلة وادي النيل للاراسات والبحوث الإنسانية والاجتماعية والتربوية (مجلة علمية محكمة)

(ISSN : 2536 - 9555)

\begin{tabular}{|c|c|c|c|c|c|c|}
\hline Test & $N$ & $M$ & $S D$ & $d f$ & $t$ & Sig. \\
\hline Pre & 20 & 12.4 & 2.7 & & & \\
\cline { 1 - 4 } Post & 20 & 28.7 & 1.2 & 35 & 35.215 & 0.000 \\
\hline
\end{tabular}

Table 2 T-test value for the pre- and post- tests for the Treatment Group

As Table 2 shows, the mean scores were 12.4 and 28.7, the standard deviations were 2.7 and 1.2 for the preand post- tests, respectively, with $d f=35, t=35.215$, and $p<0.01$. In other words, results of the $t$-test for paired samples verify the significant effect of using corpus-based activities on extending the scope of students' vocabulary.

\section{Discussion}

The participants' answers for the 'fill-in-the-gap' pro-test are shown in Tables 3 and 4 below. 
A corpus-aided discovery learning (CADL) approach to teaching collocations in TEFL settings

Dr Wesam M. A. Ibrahim \& Dr Amany A. Alsabbagh

مجلة وادي النيل للاراسات والبحوث الإنسانية والاجتماعية والتربوية (مجلة علمية محكمة)

\begin{tabular}{|l|l|l|l|l|l|}
\hline & time & people & way & years & year \\
\hline S1 & great & great & best & past & new \\
\hline S2 & great & good & effective & recent & last \\
\hline S3 & swift & nosey & easy & running & final \\
\hline S4 & good & bad & easy & long & final \\
\hline S5 & good & good & long & long & long \\
\hline S6 & good & good & short & previous & beautiful \\
\hline S7 & short & rich & best & few & 24 \\
\hline S8 & busy & famous & organized & sixty & new \\
\hline S9 & good & poor & right & long & Leap \\
\hline S10 & nice & poor & best & few & last \\
\hline S11 & hard & great & best & few & new \\
\hline S12 & hard & evil & best & twenty & previous \\
\hline S13 & good & good & easy & few & last \\
\hline S14 & bad & famous & short & Ten & new \\
\hline S15 & good & good & best & few & new \\
\hline S16 & hard & great & best & happy & New \\
\hline S17 & great & rich & effective & long & new \\
\hline S18 & bad & rich & best & few & last \\
\hline S19 & short & rich & best & three & new \\
\hline S20 & busy & poor & best & long & last \\
\hline
\end{tabular}

Table 3 The students' pre-test answers for the most frequent nouns in the $\mathrm{BNC}$ 1-5 
مجلة وادي النيل للاراسات والبحوث الإنسانية والاجتماعية والتربوية (مجلة علمية محكمة)

(ISSN : 2536 - 9555)

\begin{tabular}{|l|l|l|l|l|l|}
\hline & work & government & day & man & world \\
\hline S1 & good & good & long & tall & modern \\
\hline S2 & hard & new & good & handsome & modern \\
\hline S3 & hard & powerful & hot & handsome & developing \\
\hline S4 & hard & democratic & good & strong & small \\
\hline S5 & hard & powerful & long & old & new \\
\hline S6 & hard & new & Bad & old & modern \\
\hline S7 & much & fantastic & hot & smart & small \\
\hline S8 & hard & democratic & bad & old & universal \\
\hline S9 & hard & strong & hot & good & whole \\
\hline S10 & hard & powerful & long & handsome & whole \\
\hline S11 & good & good & happy & great & whole \\
\hline S12 & creative & democratic & bad & handsome & wonderful \\
\hline S13 & hard & democratic & hot & tall & modern \\
\hline S14 & hard & powerful & long & old & third \\
\hline S15 & hard & strong & hot & big & whole \\
\hline S16 & social & strong & hot & handsome & third \\
\hline S17 & hard & powerful & hot & strong & modern \\
\hline S18 & hard & strong & long & strong & whole \\
\hline S19 & hard & powerful & long & handsome & modern \\
\hline S20 & hard & democratic & special & strong & whole \\
\hline
\end{tabular}

Table 4 The students' pre-test answers for the most frequent nouns in the BNC 6-10

830 
A corpus-aided discovery learning (CADL) approach to teaching collocations in TEFL settings

Dr Wesam M. A. Ibrahim \& Dr Amany A. Alsabbagh

\section{مجلة وادي النيل للاراسات والبحوث الإنسانية والاجتماعية والتربوية (مجلة علمية محكمة)}

We notice the students' tendency to use the same adjectives with the nouns such as 'good', 'great' and 'hard' with time; 'good', 'great', 'poor' and 'rich' with people; 'best' and 'easy' with way; 'few' and 'long' with years; 'last' and 'new' with year; 'hard' with work; 'democratic', 'powerful' and 'strong' with government; 'hot' and 'long' with day; 'handsome', 'old' and 'strong' with man; 'whole' and 'modern' with world. This may be taken as indicative of the limited set of adjectives the participants use in the company of these nouns.

After being introduced to the $\mathrm{BNC}$, participants were required to extract the most frequent nouns in the BNC. The frequencies of the most frequent nouns in the BNC are as follows: ‘time' (152502 hits), 'people' (121591 hits), 'way' (95701 hits), 'years' (88571 hits), 'year' (73013 hits), 'work' (89319 hits), 'government' (61798 hits), 'day' (60039 hits), 'man' (58748 hits), and 'world' (57447 hits). Due to the large number of hits for each noun, we thinned the results to 100 concordances, i.e. reduced the number of results that are displayed through random selection. Then, participants were provided with the random selection of 100 concordances for each noun and asked to examine them and identify the adjectives that occur with each noun. The participants could identify the adjectives preceding each of the 10 nouns. They were required to answer the following question:

What are the adjectives that tend to come (occur frequently) with the selected nouns after investigating the concordances? Give 5 adjectives!

It should be noted that participants' answers were identical, as shown in Table 5 below, since they were provided with a printout of the same random collection of concordances. 
(ISSN : 2536 - 9555)

\begin{tabular}{|c|c|c|}
\hline & Noun & Adjectives- after investigating the concordances \\
\hline 1 & Time & same - first - long - last - short \\
\hline 2 & People & young - older - disabled -local - homeless \\
\hline 3 & Way & same - long - best - only - easiest \\
\hline 4 & Years & two - five - ten - recent - past \\
\hline 5 & Year & last - next - earlier - previous - following \\
\hline 6 & Work & hard - social - part-time - pioneering - recent \\
\hline 7 & Government & local- central- conservative- British -national \\
\hline 8 & Day & next - following - same - first - previous \\
\hline 9 & Man & young - old - tall - big - poor - handsome \\
\hline 10 & World & third - second - real - first - modern \\
\hline
\end{tabular}

Table 5 The students' extraction of the adjectives collocating with the most frequent 10 nouns in the BNC from a random selection of concordances

Participants were instructed on how to use the Collocate function on the BNC and were asked to use it for each noun, as shown in Figures 1-10 below.

\begin{tabular}{|c|c|l|c|c|c|c|}
\hline HELP & $?$ & & FREQ & ALL & MI \\
\hline 1 & $\square$ & SAME & 7983 & 60404 & 13.22 & 3.40 \\
\hline 2 & $\square$ & SPENT & 1883 & 11310 & 16.65 & 3.73 \\
\hline 3 & $\square$ & SPEND & 1552 & 7220 & 21.50 & 4.10 \\
\hline 4 & $\square$ & WASTE & 884 & 6591 & 13.41 & 3.42 \\
\hline 5 & $\square$ & SPARE & 508 & 2838 & 17.90 & 3.83 \\
\hline 6 & $\square$ & WASTING & 378 & 718 & 52.65 & 5.39 \\
\hline 7 & $\square$ & TURNOVER & 346 & 2873 & 12.04 & 3.26 \\
\hline 8 & $\square$ & WASTED & 315 & 1311 & 24.03 & 4.26 \\
\hline 9 & $\square$ & SPENDS & 211 & 736 & 28.67 & 4.51 \\
\hline 10 & $\square$ & CONSUMING & 208 & 523 & 39.77 & 4.99 \\
\hline 11 & $\square$ & DEVOTE & 170 & 585 & 29.06 & 4.53 \\
\hline 12 & $\square$ & ELAPSED & 124 & 310 & 40.00 & 4.99 \\
\hline 13 & $\square$ & TRANSIT & 98 & 862 & 11.37 & 3.18 \\
\hline 14 & $\square$ & RIPE & 83 & 609 & 13.63 & 3.44 \\
\hline 15 & $\square$ & SPAN & 82 & 715 & 11.47 & 3.19 \\
\hline 16 & $\square$ & CREDITS & 79 & 763 & 10.35 & 3.04 \\
\hline 17 & $\square$ & SAVES & 69 & 642 & 10.75 & 3.10 \\
\hline
\end{tabular}

Figure 1 A screenshot of the collocates of Time in the BNC 
A corpus-aided discovery learning (CADL) approach to teaching collocations in TEFL settings

Dr Wesam M. A. Ibrahim \& Dr Amany A. Alsabbagh

\section{مجلة وادي النيل للاراسات والبحوث الإنسانية والاجتماعية والتربوية (مجلة علمية محكمة)}

\begin{tabular}{|c|c|l|c|c|c|c|}
\hline HELP & $?$ & & FREQ & ALL & $\%$ & MI \\
\hline 1 & $\square$ & YOUNG & 3875 & 32003 & 12.11 & 3.60 \\
\hline 2 & $\square$ & OLDER & 1439 & 8599 & 16.73 & 4.07 \\
\hline 3 & $\square$ & ELDERLY & 1303 & 4877 & 26.72 & 4.74 \\
\hline 4 & $\square$ & DISABLED & 996 & 3230 & 30.84 & 4.95 \\
\hline 5 & $\square$ & KILLED & 851 & 8238 & 10.33 & 3.37 \\
\hline 6 & $\square$ & ORDINARY & 630 & 6733 & 9.36 & 3.23 \\
\hline 7 & $\square$ & THOUSANDS & 474 & 5242 & 9.04 & 3.18 \\
\hline 8 & $\square$ & DEAF & 431 & 2618 & 16.46 & 4.05 \\
\hline 9 & $\square$ & UNEMPLOYED & 376 & 2730 & 13.77 & 3.79 \\
\hline 10 & $\square$ & MENTALLY & 364 & 1938 & 18.78 & 4.24 \\
\hline 11 & $\square$ & HANDICAPPED & 287 & 1541 & 18.62 & 4.22 \\
\hline 12 & $\square$ & MILLIONS & 264 & 2578 & 10.24 & 3.36 \\
\hline 13 & $\square$ & DISABILITIES & 252 & 684 & 36.84 & 5.21 \\
\hline 14 & $\square$ & HOMELESS & 220 & 1043 & 21.09 & 4.40 \\
\hline 15 & $\square$ & EMPLOYS & 184 & 631 & 29.16 & 4.87 \\
\hline 16 & $\square$ & LIBERATION & 161 & 1706 & 9.44 & 3.24 \\
\hline
\end{tabular}

Figure 2 A screenshot of the collocates of people in the BNC

\begin{tabular}{|c|c|l|c|c|c|c|}
\hline HELP & $?$ & & FREQ & ALL & \% & MI \\
\hline 1 & $\square$ & BEHAVE & 228 & 1685 & 13.53 & 4.10 \\
\hline 2 & $\square$ & EASIEST & 170 & 758 & 22.43 & 4.83 \\
\hline 3 & $\square$ & PAVED & 142 & 356 & 39.89 & 5.66 \\
\hline 4 & $\square$ & WHICHEVER & 133 & 831 & 16.00 & 4.34 \\
\hline 5 & $\square$ & HANDLED & 111 & 1549 & 7.17 & 3.19 \\
\hline 6 & $\square$ & PAVE & 94 & 111 & 84.68 & 6.75 \\
\hline 7 & $\square$ & MILKY & 89 & 279 & 31.90 & 5.34 \\
\hline 8 & $\square$ & BEHAVED & 83 & 749 & 11.08 & 3.81 \\
\hline 9 & $\square$ & SIMPLEST & 79 & 969 & 8.15 & 3.37 \\
\hline 10 & $\square$ & QUICKEST & 75 & 214 & 35.05 & 5.48 \\
\hline 11 & $\square$ & BEHAVING & 73 & 589 & 12.39 & 3.98 \\
\hline 12 & $\square$ & PAVING & 71 & 462 & 15.37 & 4.29 \\
\hline 13 & $\square$ & PENNINE & 61 & 172 & 35.47 & 5.49 \\
\hline 14 & $\square$ & OBSTACLES & 48 & 732 & 6.56 & 3.06 \\
\hline 15 & $\square$ & ROUNDABOUT & 47 & 541 & 8.69 & 3.46 \\
\hline 16 & $\square$ & SAFEST & 43 & 276 & 15.58 & 4.31 \\
\hline
\end{tabular}

Figure 3 A screenshot of the collocates of way in the BNC 
مجلة وادي النيل للاراسات والبحوث الإنسانية والاجتماعية والتربوية (مجلة علمية محكمة)

(ISSN : 2536 - 9555)

\begin{tabular}{|c|c|l|c|c|c|c|}
\hline HELP & $?$ & & FREQ & ALL & \% & MI \\
\hline 1 & $\square$ & AGO & 10190 & 19057 & 53.47 & 6.20 \\
\hline 2 & $\square$ & TWO & 8953 & 150883 & 5.93 & 3.03 \\
\hline 3 & $\square$ & OVER & 8831 & 128515 & 6.87 & 3.24 \\
\hline 4 & $\square$ & THREE & 6286 & 77467 & 8.11 & 3.48 \\
\hline 5 & $\square$ & FIVE & 5418 & 39453 & 13.73 & 4.24 \\
\hline 6 & $\square$ & LAST & 4370 & 73564 & 5.94 & 3.03 \\
\hline 7 & $\square$ & FEW & 3551 & 42792 & 8.30 & 3.51 \\
\hline 8 & $\square$ & TEN & 3528 & 19418 & 18.17 & 4.64 \\
\hline 9 & $\square$ & FOUR & 3512 & 44797 & 7.84 & 3.43 \\
\hline 10 & $\square$ & LATER & 3476 & 37936 & 9.16 & 3.65 \\
\hline 11 & $\square$ & PAST & 3002 & 25086 & 11.97 & 4.04 \\
\hline 12 & $\square$ & RECENT & 2813 & 15474 & 18.18 & 4.64 \\
\hline 13 & $\square$ & TWENTY & 2277 & 15208 & 14.97 & 4.36 \\
\hline 14 & $\square$ & SIX & 1915 & 29444 & 6.50 & 3.16 \\
\hline 15 & $\square$ & 20 & 1745 & 13391 & 13.03 & 4.16 \\
\hline 16 & $\square$ & 10 & 1716 & 18907 & 9.08 & 3.64 \\
\hline 17 & $\square$ & SEVEN & 1659 & 16878 & 9.83 & 3.76 \\
\hline 18 & $\square$ & HUNDRED & 1423 & 18576 & 7.66 & 3.40 \\
\hline & & & & & & 9 \\
\hline
\end{tabular}

Figure 4 A screenshot of the collocates of years in the BNC

\begin{tabular}{|c|c|l|c|c|c|c|}
\hline HELP & $?$ & & FREQ & ALL & $9 \%$ & MI \\
\hline 1 & $\square$ & LAST & 10781 & 73564 & 14.66 & 4.61 \\
\hline 2 & $\square$ & NEXT & 4387 & 44416 & 9.88 & 4.04 \\
\hline 3 & $\square$ & MILLION & 1273 & 23707 & 5.37 & 3.16 \\
\hline 4 & $\square$ & EARLIER & 1110 & 16145 & 6.88 & 3.52 \\
\hline 5 & $\square$ & AGO & 1083 & 19057 & 5.68 & 3.24 \\
\hline 6 & $\square$ & PREVIOUS & 959 & 11866 & 8.08 & 3.75 \\
\hline 7 & $\square$ & 200O & 479 & 1631 & 29.37 & 5.61 \\
\hline 8 & $\square$ & BILLION & 478 & 4556 & 10.49 & 4.13 \\
\hline 9 & $\square$ & OLDS & 422 & 468 & 90.17 & 7.23 \\
\hline 10 & $\square$ & 31 & 410 & 4713 & 8.70 & 3.86 \\
\hline 11 & $\square$ & PROFITS & 307 & 5742 & 5.35 & 3.16 \\
\hline 12 & $\square$ & PROFIT & 289 & 5842 & 4.95 & 3.04 \\
\hline 13 & $\square$ & FISCAL & 210 & 1288 & 16.30 & 4.77 \\
\hline 14 & $\square$ & EVE & 174 & 1537 & 11.32 & 4.24 \\
\hline 15 & $\square$ & TONNES & 172 & 1796 & 9.58 & 4.00 \\
\hline 16 & $\square$ & ENDING & 150 & 2284 & 6.57 & 3.45 \\
\hline 17 & $\square$ & CALENDAR & 133 & 1066 & 12.48 & 4.38 \\
\hline 18 & $\square$ & ANNIVERSARY & 120 & 1995 & 6.02 & 3.33 \\
\hline
\end{tabular}

Figure 5 A screenshot of the collocates of year in the BNC

$(834)$ 
A corpus-aided discovery learning (CADL) approach to teaching collocations in TEFL settings

Dr Wesam M. A. Ibrahim \& Dr Amany A. Alsabbagh

\begin{tabular}{|c|c|c|c|c|c|c|}
\hline HELP & $?$ & & FREQ & ALL & $\%$ & MI \\
\hline 1 & 回 & HARD & 2022 & 21766 & 9.29 & 3.66 \\
\hline 2 & 回 & UNDERTAKEN & 253 & 2685 & 9.42 & 3.68 \\
\hline 3 & 回 & PART-TIME & 227 & 2046 & 11.09 & 3.91 \\
\hline 4 & 回 & HARDER & 183 & 2319 & 7.89 & 3.42 \\
\hline 5 & 口 & UNDERTAKE & 140 & 1726 & 8.11 & 3.46 \\
\hline 6 & $\square$ & RESTORATION & 124 & 1900 & 6.53 & 3.15 \\
\hline 7 & 口 & PIONEERING & 95 & 572 & 16.61 & 4.49 \\
\hline 8 & 回 & EMPIRICAL & 93 & 1490 & 6.24 & 3.08 \\
\hline 9 & 回 & CLERICAL & 74 & 900 & 8.22 & 3.48 \\
\hline 10 & 口 & EFFICIENTLY & 65 & 1072 & 6.06 & 3.04 \\
\hline 11 & $\square$ & ETHIC & 63 & 255 & 24.71 & 5.07 \\
\hline 12 & 回 & PREPARATORY & 61 & 392 & 15.56 & 4.40 \\
\hline 13 & 回 & COMMENCED & 48 & 651 & 7.37 & 3.32 \\
\hline 14 & 回 & OVERTIME & 48 & 654 & 7.34 & 3.32 \\
\hline 15 & 回 & REPORTERS & 48 & 705 & 6.81 & 3.21 \\
\hline 16 & 口 & REMEDIAL & 47 & 326 & 14.42 & 4.29 \\
\hline 17 & 回 & UNPAID & 47 & 579 & 8.12 & 3.46 \\
\hline 18 & $\square$ & MISSIONARY & 46 & 576 & 7.99 & 3.44 \\
\hline
\end{tabular}

Figure 6 A screenshot of the collocates of work in the BNC

\begin{tabular}{|c|c|l|l|l|l|l|}
\hline HELP & $?$ & FREQ & ALL & \% & MI \\
\hline 1 & $\square$ & LOCAL & 4421 & 45552 & 9.71 & 4.28 \\
\hline 2 & $\square$ & CENTRAL & 1941 & 18738 & 10.36 & 4.38 \\
\hline 3 & $\square$ & LABOUR & 1441 & 26519 & 5.43 & 3.45 \\
\hline 4 & $\square$ & POLICY & 1412 & 25443 & 5.55 & 3.48 \\
\hline 5 & $\square$ & CONSERVATIVE & 718 & 6920 & 10.38 & 4.38 \\
\hline 6 & $\square$ & ANNOUNCED & 617 & 9853 & 6.26 & 3.65 \\
\hline 7 & $\square$ & POLICIES & 531 & 8674 & 6.12 & 3.62 \\
\hline 8 & $\square$ & FEDERAL & 523 & 3413 & 15.32 & 4.94 \\
\hline 9 & $\square$ & DEPARTMENTS & 492 & 4186 & 11.75 & 4.56 \\
\hline 10 & $\square$ & SPENDING & 452 & 6449 & 7.01 & 3.81 \\
\hline 11 & $\square$ & COALITION & 423 & 2227 & 18.99 & 5.25 \\
\hline 12 & $\square$ & EXPENDITURE & 401 & 5408 & 7.41 & 3.89 \\
\hline 13 & $\square$ & OFFICIALS & 384 & 5915 & 6.49 & 3.70 \\
\hline 14 & $\square$ & LEADERS & 306 & 6941 & 4.41 & 3.14 \\
\hline 15 & $\square$ & FINANCE & 297 & 7200 & 4.13 & 3.05 \\
\hline 16 & $\square$ & PROPOSALS & 280 & 6695 & 4.18 & 3.07 \\
\hline 17 & $\square$ & MINISTERS & 264 & 6449 & 4.09 & 3.04 \\
\hline 18 & $\square$ & FUNDING & 251 & 4276 & 5.87 & 3.56 \\
\hline
\end{tabular}

Figure 7 A screenshot of the collocates of government in the BNC 
مجلة وادي النيل للاراسات والبحوث الإنسانية والاجتماعية والتربوية (مجلة علمية محكمة)

(ISSN : 2536 - 9555)

\begin{tabular}{|c|c|c|c|c|c|c|}
\hline HELP & $?$ & & FREQ & ALL & 9 & $\mathrm{MI}$ \\
\hline 1 & 回 & EVERY & 3342 & 38600 & 8.66 & 4.13 \\
\hline 2 & $\square$ & DAY & 2557 & 59298 & 4.31 & 3.13 \\
\hline 3 & 回 & NEXT & 2498 & 44416 & 5.62 & 3.51 \\
\hline 4 & 回 & FOLLOWING & 1086 & 26057 & 4.17 & 3.08 \\
\hline 5 & $\square$ & HOURS & 808 & 18073 & 4.47 & 3.18 \\
\hline 6 & $\square$ & CHRISTMAS & 478 & 8512 & 5.62 & 3.51 \\
\hline 7 & $\square$ & BOXING & 283 & 1207 & 23.45 & 5.57 \\
\hline 8 & 回 & WEDDING & 200 & 3172 & 6.31 & 3.68 \\
\hline 9 & $\square$ & SUNNY & 161 & 964 & 16.70 & 5.08 \\
\hline 10 & 回 & POLLING & 113 & 480 & 23.54 & 5.58 \\
\hline 11 & 回 & MEALS & 111 & 2322 & 4.78 & 3.28 \\
\hline 12 & 回 & BARRELS & 105 & 544 & 19.30 & 5.29 \\
\hline 13 & 回 & VALENTINE & 86 & 311 & 27.65 & 5.81 \\
\hline 14 & 回 & SEVENTH & 82 & 1437 & 5.71 & 3.53 \\
\hline 15 & $\square$ & TRIPS & 81 & 1315 & 6.16 & 3.64 \\
\hline 16 & $\square$ & RAINY & 75 & 232 & 32.33 & 6.04 \\
\hline 17 & $\square$ & CALORIES & 75 & 798 & 9.40 & 4.25 \\
\hline 18 & 回 & CIGARETTES & 75 & 1255 & 5.98 & 3.60 \\
\hline
\end{tabular}

Figure 8 A screenshot of the collocates of day in the BNC

\begin{tabular}{|c|c|l|c|c|c|c|}
\hline HELP & $?$ & FREQ & ALL & \% & MI \\
\hline 1 & $\square$ & YOUNG & 2806 & 32003 & 8.77 & 4.18 \\
\hline 2 & $\square$ & OLD & 2546 & 52171 & 4.88 & 3.34 \\
\hline 3 & $\square$ & WOMAN & 940 & 21791 & 4.31 & 3.16 \\
\hline 4 & $\square$ & TALL & 405 & 4296 & 9.43 & 4.29 \\
\hline 5 & $\square$ & ISLE & 347 & 1341 & 25.88 & 5.74 \\
\hline 6 & $\square$ & HANDSOME & 143 & 1570 & 9.11 & 4.24 \\
\hline 7 & $\square$ & BLIND & 121 & 3018 & 4.01 & 3.05 \\
\hline 8 & $\square$ & MIDDLE-AGED & 120 & 691 & 17.37 & 5.17 \\
\hline 9 & $\square$ & BRAVE & 82 & 1704 & 4.81 & 3.32 \\
\hline 10 & $\square$ & INTELLIGENT & 78 & 1820 & 4.29 & 3.15 \\
\hline 11 & $\square$ & UTD & 71 & 213 & 33.33 & 6.11 \\
\hline 12 & $\square$ & WEALTHY & 71 & 1309 & 5.42 & 3.49 \\
\hline 13 & $\square$ & BEARDED & 70 & 322 & 21.74 & 5.49 \\
\hline 14 & $\square$ & BALD & 56 & 608 & 9.21 & 4.25 \\
\hline 15 & $\square$ & CHARMING & 56 & 1324 & 4.23 & 3.13 \\
\hline 16 & $\square$ & RIGHT-HAND & 54 & 608 & 8.88 & 4.20 \\
\hline 17 & $\square$ & JAILED & 54 & 807 & 6.69 & 3.79 \\
\hline 18 & $\square$ & BEARD & 54 & 882 & 6.12 & 3.66 \\
\hline
\end{tabular}

Figure 9 A screenshot of the collocates of man in the BNC

$(836)$ 
A corpus-aided discovery learning (CADL) approach to teaching collocations in TEFL settings

Dr Wesam M. A. Ibrahim \& Dr Amany A. Alsabbagh

\begin{tabular}{|c|c|c|c|c|c|c|}
\hline HELP & $?$ & & FREQ & ALL & $\%$ & $\mathrm{MI}$ \\
\hline 1 & $\square$ & WAR & 3937 & 26881 & 14.65 & 4.96 \\
\hline 2 & 回 & CUP & 2162 & 11774 & 18.36 & 5.28 \\
\hline 3 & 回 & THIRD & 1795 & 20426 & 8.79 & 4.22 \\
\hline 4 & 回 & SECOND & 1792 & 40249 & 4.45 & 3.24 \\
\hline 5 & 回 & OUTSIDE & 915 & 20846 & 4.39 & 3.22 \\
\hline 6 & $\square$ & BANK & 883 & 17031 & 5.18 & 3.46 \\
\hline 7 & $\square$ & THROUGHOUT & 713 & 12126 & 5.88 & 3.64 \\
\hline 8 & $\square$ & ARAB & 606 & 2486 & 24.38 & 5.69 \\
\hline 9 & $\square$ & CHAMPION & 605 & 3315 & 18.25 & 5.28 \\
\hline 10 & 口 & PARTS & 536 & 11394 & 4.70 & 3.32 \\
\hline 11 & $\square$ & CHAMPIONSHIP & 493 & 3293 & 14.97 & 4.99 \\
\hline 12 & 口 & MIDDLE & 484 & 12447 & 3.89 & 3.05 \\
\hline 13 & 回 & LARGEST & 459 & 5640 & 8.14 & 4.11 \\
\hline 14 & $\square$ & WESTERN & 396 & 9586 & 4.13 & 3.13 \\
\hline 15 & $\square$ & $॥$ & 372 & 8638 & 4.31 & 3.19 \\
\hline 16 & 回 & CHAMPIONSHIPS & 370 & 1491 & 24.82 & 5.72 \\
\hline 17 & 口 & $\mathrm{BBC}$ & 287 & 4154 & 6.91 & 3.87 \\
\hline 18 & $\square$ & MARKETS & 274 & 5761 & 4.76 & 3.34 \\
\hline
\end{tabular}

Figure 10 A screenshot of the collocates of world in the BNC

Participants were then asked to extract the collocations; examine the list of the (100) most statistically significant collocates with each noun; and extract the adjectives from each list, see Table 6. 
مجلة وادي النيل للاراسات والبحوث الإنسانية والاجتماعية والتربوية (مجلة علمية محكمة)

(ISSN : 2536 - 9555)

\begin{tabular}{|c|c|c|}
\hline & Noun & Collocating adjectives \\
\hline 1 & Time & same - first - long - last - short - next - second \\
\hline 2 & People & $\begin{array}{l}\text { young - other - elderly - older - disabled - ordinary - } \\
\text { local - unemployed - handicapped - working - } \\
\text { homeless - different }\end{array}$ \\
\hline 3 & Way & same - long - best - only - easiest - wrong - effective \\
\hline 4 & Years & $\begin{array}{l}\text { two }- \text { five }- \text { three }- \text { ten }- \text { recent }- \text { past }- \text { four }- \text { last }- \\
\text { twenty }- \text { next }- \text { seven }- \text { thirty }- \text { hundred }- \text { several }- \\
\text { eight }- \text { fifteen }- \text { fifty }- \text { earlier }- \text { early }- \text { previous }\end{array}$ \\
\hline 5 & Year & $\begin{array}{l}\text { last }- \text { next }- \text { earlier }- \text { previous }- \text { following }- \text { million }- \\
\text { first }- \text { new }- \text { financial }- \text { billion }- \text { past }- \text { same }- \text { fiscal }- \\
\text { second }- \text { third }- \text { current }\end{array}$ \\
\hline 6 & Work & $\begin{array}{l}\text { hard - social - part-time }- \text { art }- \text { pioneering }- \text { recent }- \\
\text { voluntary }- \text { ethic }\end{array}$ \\
\hline 7 & Government & $\begin{array}{l}\text { local }- \text { central }- \text { Labour }- \text { conservative }- \text { federal }- \\
\text { British - coalition - national - interim }- \text { provisional }- \\
\text { new }- \text { transitional - elected }\end{array}$ \\
\hline 8 & Day & $\begin{array}{l}\text { every }- \text { next }- \text { one }- \text { following }- \text { boxing }- \text { same }- \\
\text { Christmas - first }- \text { previous - present }- \text { other }- \text { sunny - } \\
\text { wedding - valentine - rainy - working - last - hot }\end{array}$ \\
\hline 9 & Man & $\begin{array}{l}\text { young }- \text { old }- \text { tall }- \text { dead }- \text { big }- \text { married }- \text { middle-aged } \\
- \text { poor }- \text { handsome }- \text { older }- \text { white }- \text { rich }- \text { thin }- \\
\text { bearded }- \text { blind }- \text { younger }- \text { loved }- \text { nice }- \text { fat }- \text { honest } \\
\text { - black }- \text { elderly }\end{array}$ \\
\hline 10 & World & $\begin{array}{l}\text { third }- \text { second }- \text { Arab }- \text { real }- \text { first }- \text { largest }- \text { east }- \\
\text { whole }- \text { western - modern - developing - wide }\end{array}$ \\
\hline
\end{tabular}

Table 6 The students' extraction of the adjectives collocating with the most frequent 10 nouns in the BNC, using the COLLOCATION function

Then, participants were asked to answer the fill-in-the-gap activity in Table 1, which they had attempted earlier (post-test). This is followed by a number of activities including the following. 


\section{A corpus-aided discovery learning (CADL) approach to teaching collocations in TEFL settings}

Dr Wesam M. A. Ibrahim \& Dr Amany A. Alsabbagh

مجلة وادي النيل للاراسات والبحوث الإنسانية والاجتماعية والتربوية (مجلة علمية محكمة)

\section{Activity 1}

Students were asked to form groups of four and use the random collections of concordances provided below to identify collocational patterns (adjective + noun).

\section{Sample 1 Random collection of concordances of time}

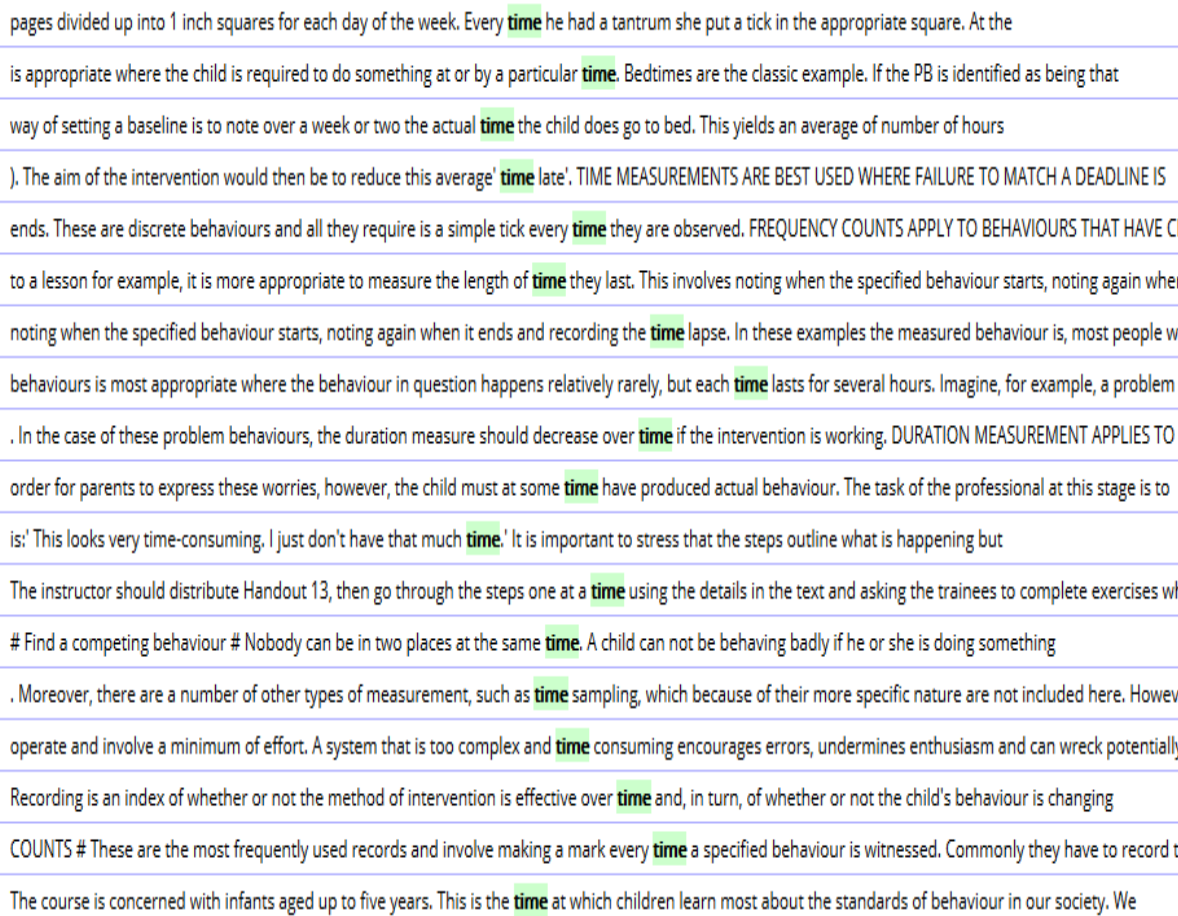


(ISSN : 2536 - 9555)

\section{Sample 2 Random collection of concordances of people}

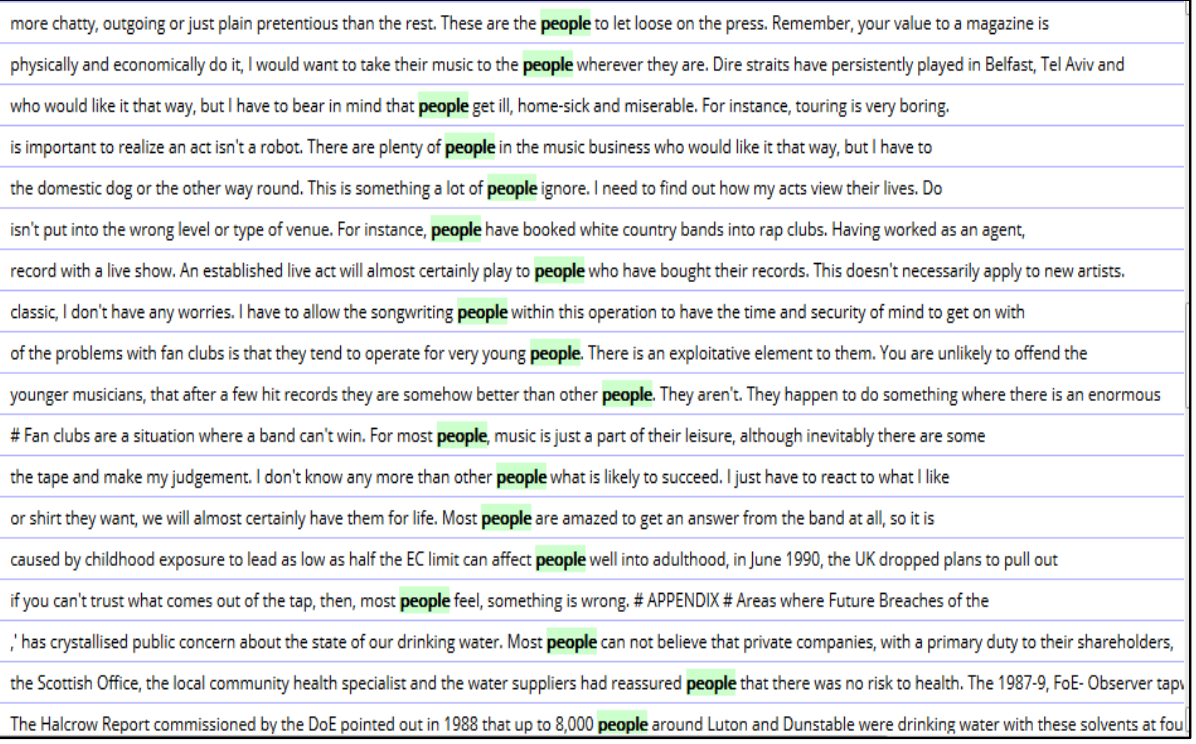

\section{Sample 3 Random collection of concordances of way}

was told to put Gabriel in the charge of his daughter, and led the way. He did not put a hand on Gabriel's shoulder.' I'm

saw a play before,' said Gabriel, to indicate in the politest possible way that he did not understand one word of what Lucie was telling him.'

we're liked. You liked us.' She had a bald, stark way of speaking, never looking Gabriel in the eye but staring over his shoulder with

TEN \# THE PETITION \# BURN EVERYTHING, said Lucie. It's the only way. So they put a torch to the Mason's wagon and, as the

But l'll get it straight at Walsingham. I'll walk all the way, and in my bare feet, too... You could pray for me,

the likes of you... I must be starting out now. It's a way to go, I think. And on foot.' He took off his

an angel, no more than any of us. But look at it my way: I never thought you were. I knew all along that you weren't

out long since." I did! But in a sort of a way... oh, out there! Out there and in here! I want a

ninety gallons of each a week. The beer is made in as traditional a way as possible, using the finest malt, only whole hops and no sugars.

It was his life. If he had to go I think that was the way he would have wanted it Voice over Mr Moore had been displaying the Spitfire for

, two buffons macaws and a hyacinth macaw were taken by thieves who forced their way into cages at a Bird Sanctuary in Cornwall. Police found the birds wrap

productions. But the trust denies this. It says the move is the only way to keep the theatre open. He says the public won't notice any difference

died because of all the smoke and flames. There's praise tonight for the way the twins father quickly got the children clear of the smoke and flames: He

the girls to Yorkshire but local boy Ray Powell raised the roof by fighting his way through to the semi-finals \# Five firms facing charges over the death of a Glouc

fuel. One of the more than a hundred and thirty children who die that way every year. The aim of the tv campaign is to get parents to wonder

misfit. Something vulnerable in her manner brings out an element of sadism in the way the long final act teases her endurance; but it also makes the denouem

three stitches at right of centre on to the second transfer tool in the same way. Move the second transfer tool from the right to the left and slide the

over the next two needles and so on. This is a fairly easy way to produce brands of pattern on machines of this type. When weaving on a 


\title{
A corpus-aided discovery learning (CADL) approach to teaching collocations in TEFL settings \\ Dr Wesam M. A. Ibrahim \& Dr Amany A. Alsabbagh
}

\author{
مجلة وادي النيل للاراسات والبحوث الإنسانية والاجتماعية والتربوية (مجلة علمية محكمة)
}

\section{Sample 4 Random collection of concordances of years}

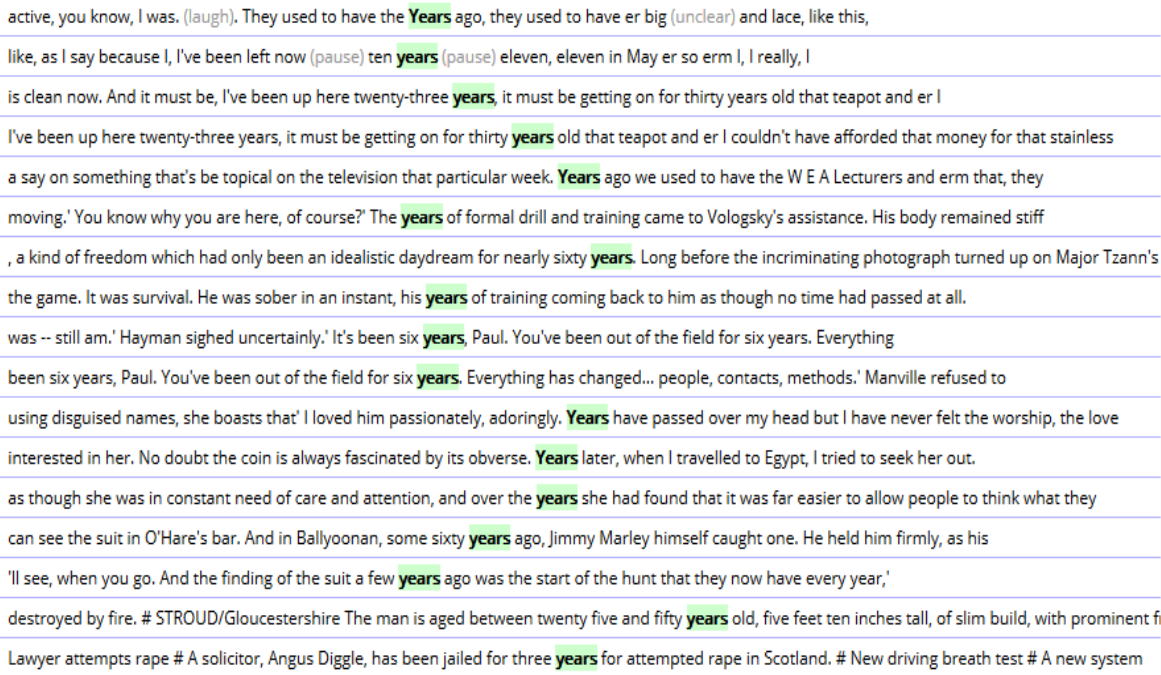

\section{Sample 5 Random collection of concordances of year}

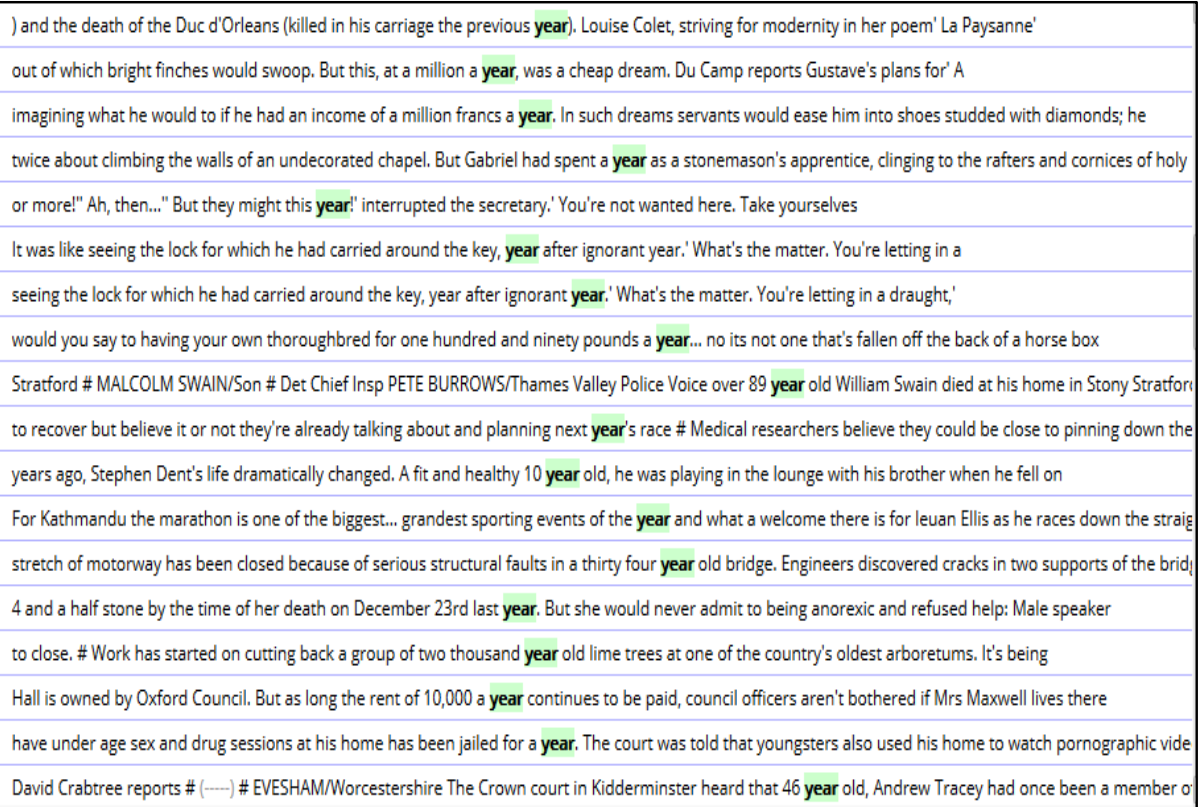

$841)$ 
(ISSN : 2536 - 9555)

\section{Sample 6 Random collection of concordances of work}

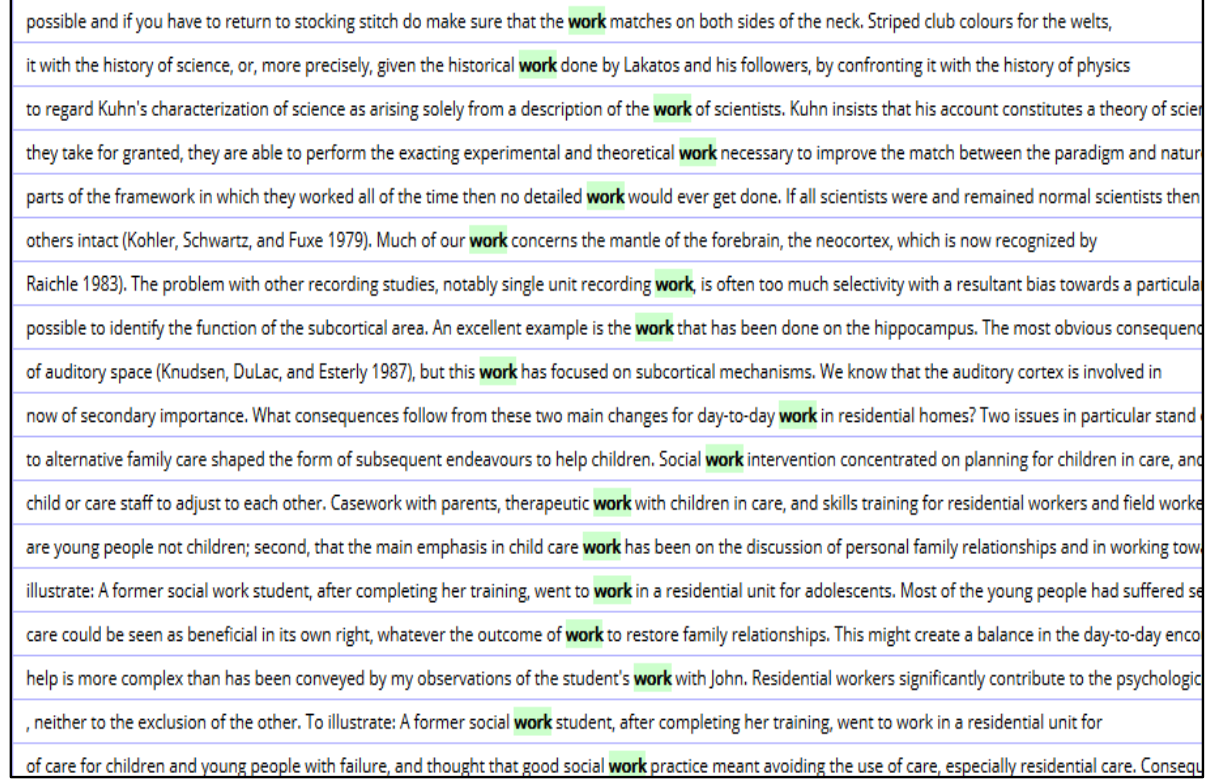

\section{Sample 7 Random collection of concordances of government}

platform. Her supporters in the audience made it clear that her recent attacks on Government policy have, if anything, made her more popular with party activis submit a full planning application. \# The Bishop of Oxford has appealed to the Government not to cut aid to the Third World. He says it would be morally an open letter to local MPs which includes frontline Ministers. But tonight, the Government couldn't give any assurances about overseas aid. Gargy Patel reports. David Bryer says by cutting Third World aid to help reduce public spending, the Government would be cutting off it's nose to spite it's face. The effect who are powerless, says the Bishop of $O x f o r d$, without the help of this Government and those of other developed countries. And they would face certain disaster ... and at three pounds each, they're ten pounds cheaper than the official Government version. Male speaker l've actually read it three times The idea was born in - Male speaker We feel people have a right to read this and if the Government isn't going to help them, we are Female speaker After the French Referendum An RAF base which had been due to close next year as part of the Government's defence cuts is stay open and be taken over by the army. The

scheduled to close next April as part of Options for Change'... the government's restructuring of defence. The parachute packing hanger had been destroyed by post of Swindon's Economic director has led to anger and protest. The Local Government union NALGO calls it an infamous act of betrayal to Jamie Robertson, w one of the most self-contained parts of the British Rail network, factors which the Government believes will make it attractive to investors. Privatisation will be th Victims of the Maxwell pensions scandal have set up an action committee to press the Government for compensation. They also plan to campaign for new laws te the Commons the rail unions protested at today's announcement. Their leaders said the Government was asset stripping British Rail. R01/31/93 21:11 pah 0:15 h The news came as a complete surprise to workers at the Oxfordshire base. The Government says it will work to salvage a long term future for the company. But rejected any idea of an immediate cut in interest rates. \# 1 \# The Government has limited public sector pay rises to one point five per cent, although teachers attacked Becky were destroyed the same day. Great Danes are not affected by the Government's dangerous dogs legislation. \# Good evening. \# ANNE DAWSON major cases like this leg reconstruction, there's little competition. But under the Government's health reforms, routine surgery like a knee replacement, can easily . The proceedings are expected to last 2 days. \# Health watchdogs fear the Government's NHS reforms could mean hundreds of hospital patients will have to tray 


\title{
A corpus-aided discovery learning (CADL) approach to teaching collocations in TEFL settings \\ Dr Wesam M. A. Ibrahim \& Dr Amany A. Alsabbagh
}

\author{
مجلة وادي النيل للاراسات والبحوث الإنسانية والاجتماعية والتربوية (مجلة علمية محكمة)
}

Sample 8 Random collection of concordances of day

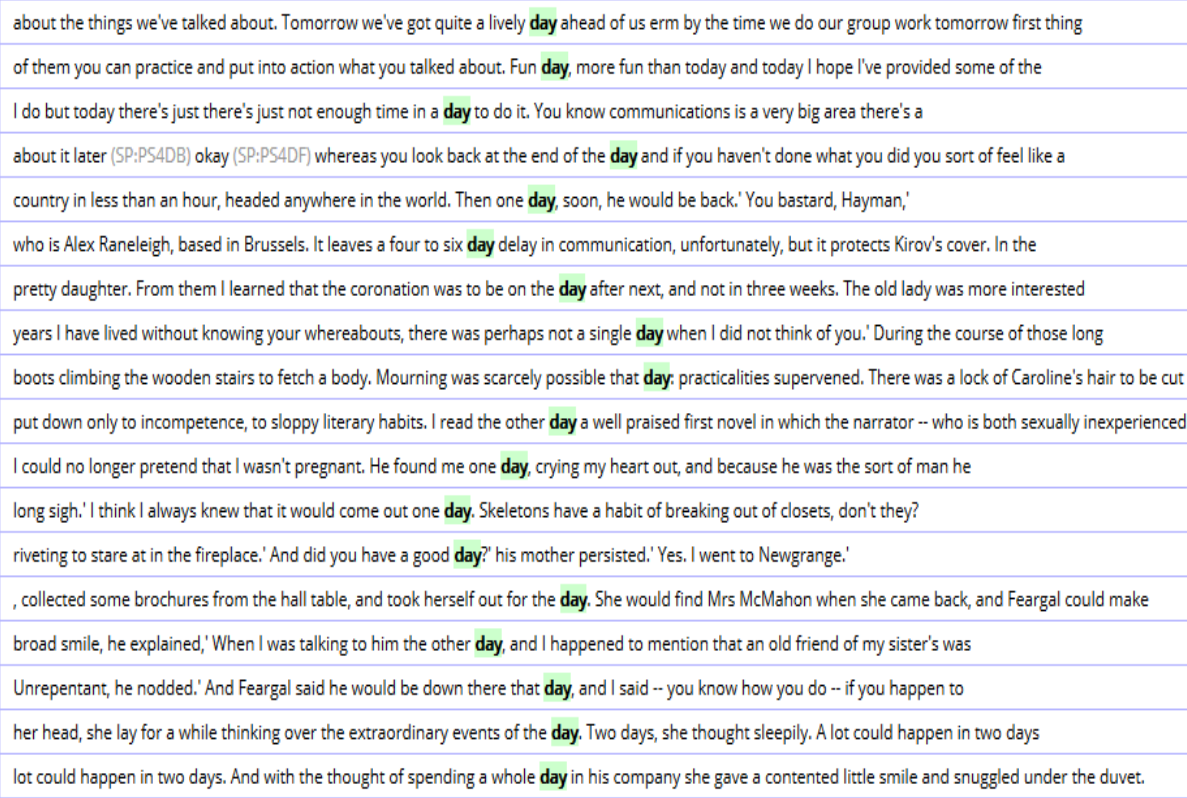

\section{Sample 9 Random collection of concordances of man}

was puzzled even more, but he took the hint. Somehow, the old man had let out a dangerous secret, one which could not be discussed in a was stunned.' Murdered? Why?" Your father was a brave man,' Kirov went on.' He dared to feel, as many of

be in direct touch with the pilot. Phasenko was a cell-link, a contact man only. He had never been used for a hit, and it was unlikely

still counting on over 40 safe hours, Manville left his office. The condemned man had failed to eat a hearty breakfast, and lunch had consisted of two tacos

three cups of coffee. There was little point, Manville decided, on a man eating on an empty stomach. He went straight to the nearest bar, where seated at his desk, holding it between trembling fingers. He could imagine the man's eyes, filled with loathing and disgust, unable to register the full extent

of a surgeon's scalpel. The inner robot switched off, leaving the conscious man to cope with real problems, the immediacy of living. Pumping adrenalin lent a heard a thin squeal of pain and sensed, rather than actually saw, a man topple sideways into the gutter. A searing fire of elation bathed him suddenly, Before ducking back into cover, he was rewarded by a clear sight of a man falling back behind the Dodge, Manville's bullet buried in his stomach. He waiting, thinking. They would try a rush next, he predicted. One man to come out of cover, to draw his fire, while the remaining operative the ground and rolled out of the doorway on to the sidewalk. The fourth man, caught without cover, had no chance at all. Manville loosed three shots the slugs finding a mark in his chest. With a horrible gurgle, the man toppled backwards to lay across the trunk of the car, finally slithering down it was a solid counter-measure. You simply resisted your natural temptation to worry about the man breaking cover, and took the hit-man before he took you. Conv the temptation to shift focus. Exactly as expected, the shape of the second man emerged suddenly above the car's hood, ready to pump bullets towards Manville' bind him to reality. He was still, for the moment, a military man. Therefore, he followed orders. He was a pilot. It was his of the Potomac River. \# Kirov's face bore the unmistakable look of a man who has deliberately walked into a cage of lions and emerged again unscathed. Surprise night-fighting technique in group tactics. Right at the beginning of a gun-fight, one man feigns a hit, screams, and goes down. He stays down, just terribly wrong. He could have failed to get a personal interview with the one man with whom he had some sort of contact. His request could have been investigate 
(ISSN : 2536 - 9555)

\section{Sample 10 Random collection of concordances of world}

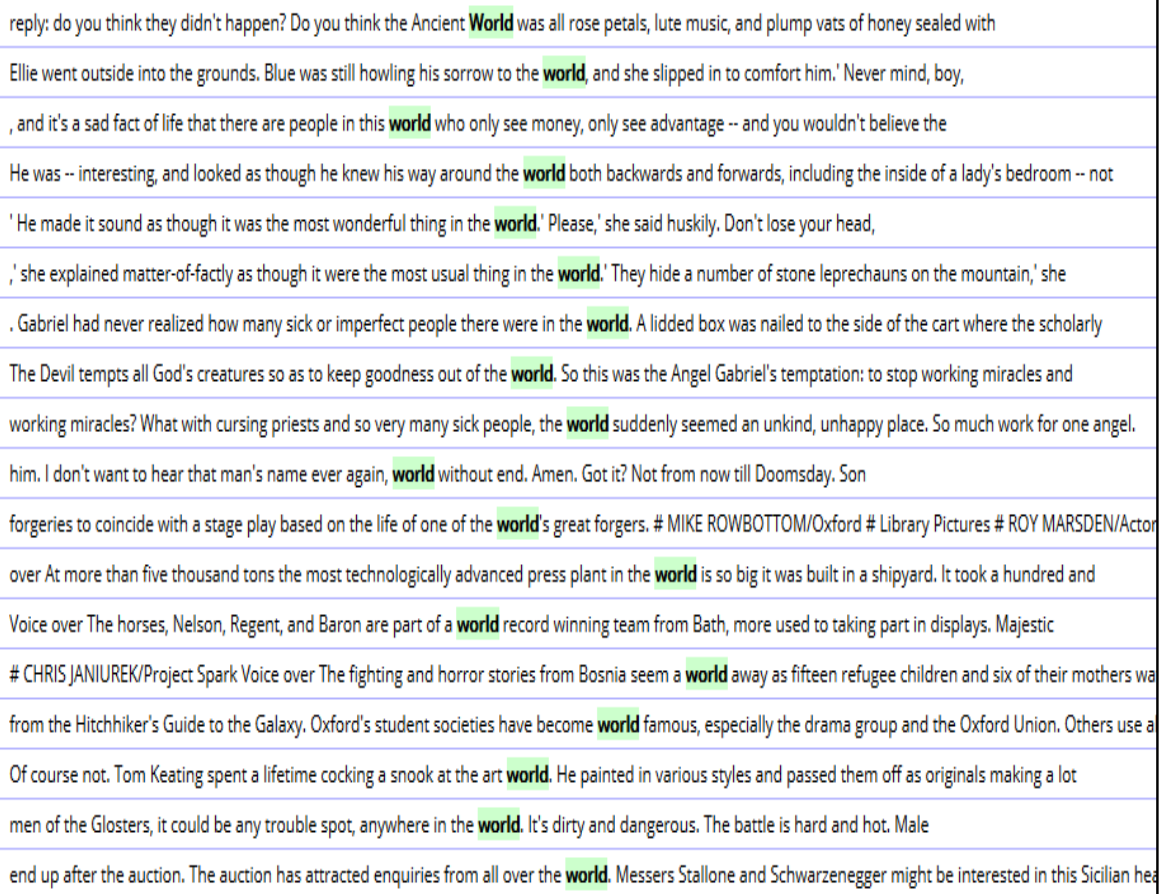

\section{Activity 2}

Students were asked to use each pattern [adjective + noun] they have extracted in Activity 1 to produce at least two sentences of their own.

Note that this activity requires students to go beyond just identifying the patterns in the concordance lines and come up with their own sentences, i.e., put these patterns into use. 
A corpus-aided discovery learning (CADL) approach to teaching collocations in TEFL settings

Dr Wesam M. A. Ibrahim \& Dr Amany A. Alsabbagh

مجلة وادي النيل للاراسات والبحوث الإنسانية والاجتماعية والتربوية (مجلة علمية محكمة)

\section{Conclusion}

The research question addressed in this paper (i.e., 'Would the use of corpus-aided discovery learning activities have an impact on extending the scope of students' vocabulary?') was clearly answered in the discussion of the task. We have presented an example for the possibility of using a corpus-aided discovery learning (CADL) approach in teaching/learning vocabulary. The use of CADL activities in the classroom was quite advantageous since they allowed students to examine the vocabulary in their natural context, to learn vocabulary in frequently occurring combinations and to store a variety of expressions that they may not be able to create by themselves. The effectiveness of the CADL approach was confirmed by the wider scope of the vocabulary used by students after the task as compared to their narrow choices of vocabulary items before using the CADL approach.

This paper provides a practical example of how corpora can be put to use in the English language classroom. Corpus data are resources that provide descriptive insights relevant to how people use language and provide tools that enable learners to analyse how people use different language forms. The use of the CADL approach provides learners with the possibility to enrich their vocabulary by increasing the number of adjectives they can use with each noun. It also provides learners with access to some information about the culture of the British people from the authentic material ${ }^{4}$. It also accords with the principles of datadriven learning and promotes students' discovery-based learning by

${ }^{4}$ In one of the concordances of the noun 'day', the participants came across the pattern 'Boxing day' and we discussed the significance of this day in British culture. Boxing Day is a holiday celebrated on the day after Christmas Day, i.e., the $26^{\text {th }}$ of December. Currently, Boxing Day is primarily known as a shopping holiday since it is characterised by huge discounts on most items in the shops. 
مجلة وادي النيل للاراسات والبحوث الإنسانية والاجتماعية والتربوية (مجلة علمية محكمة)

(ISSN : 2536 - 9555)

encouraging them to detect linguistic patterns by themselves. It should be noted that the learning activities employed in this study are consistent with the current principles of language learning theory, that is, learners develop more autonomy when they receive guidance about how to observe language and detect patterns.

\section{References}

Adolphs, S \& Lin, P.M.S. (2011). 'Corpus Linguistics'. In J. Simpson (Ed.), The Routledge Handbook of Applied Linguistics. The Linguist and the Translator. London: Routledge, pp. 597-610.

Aijmer, K. (2009). 'Introduction: Corpora and language teaching'. In K. Aijmer (Ed.), Corpora and language teaching. Amsterdam: John Benjamins, pp. 1-10.

Aston, G. (2001). 'Learning with corpora: An overview'. In G. Aston (ed.), Learning with corpora. Houston: Athelstan, pp. $7-45$.

Aston, G., Bernardini, S., \& Stewart, D. (2004). Corpora and language learners. Amsterdam: John Benjamins.

Baker, P., Hardie, A., \& McEnery, T. (2006). A Glossary of Corpus Linguistics. Edinburgh: Edinburgh University Press.

Baker, P. (2010). Sociolinguistics and Corpus Linguistics. Edinburgh: Edinburgh University Press.

Bassnett, S. (2002). Translation Studies. London: Routledge.

Bernerdini, S. (2000). 'Systematising serendipity: Proposals for concordancing large corpora with language learners'. In L. Burnard and T. McEnery (eds.). Rethinking Language Pedagogy from a Corpus Perspective: Papers from the third international conference on Teaching and Language Corpora. Frankfurt am Main: Peter Lang, pp. 225-234. 
A corpus-aided discovery learning (CADL) approach to teaching collocations in TEFL settings

Dr Wesam M. A. Ibrahim \& Dr Amany A. Alsabbagh

$$
\text { مجلة وادي النيل للاراسات والبحوث الإنسانية والاجتماعية والتريوية (مجلة علمية محكمة) }
$$

Bernardini, S. (2002). 'Exploring New Directions for Discovery Learning'. In B. Kettemann and G. Marko (eds.), Teaching and Learning by Doing Corpus Analysis. Proceedings of the Fourth International Conference on Teaching and Language Corpora. Amsterdam: Rodopi. pp. 165-182.

Bernardini, S. (2004). "Corpora in the Classroom.” In J. Sinclair's (ed.) How to Use Corpora in Language Teaching. Amsterdam: Benjamins, pp. 15-36.

Bernardini, S. (2016). 'DISCOVERY LEARNING IN THE LANGUAGE-FOR-TRANSLATION CLASSROOM: CORPORA AS LEARNING AIDS'. Cadernos de Tradução, 36(spe), 14-35. https://doi.org/10.5007/21757968.2016v36nesp1p14

Biber, D., Conrad, S. \& Reppen, R. (1998). Corpus linguistics: Investigating language structure and use. Cambridge: Cambridge University Press.

Biber, D., Johansson, S., Leech, G., Conrad, S. and Finegan, E. (1999). Longman Grammar of Spoken and Written English. Harlow: Pearson Education.

Boulton, A. (2011). "Data-driven Learning: The Perpetual Enigma.” In Stanisław Gód-Roszkowski's (ed.) Explorations across Languages and Corpora. Frankfurt: Peter Lang, pp. 563-580.

Braun, S., K. Kohn \& J. Mukherjee (eds.). (2006). Corpus Technology and Language Pedagogy. New Resources, New Tools, New Methods. Frankfurt am Main: Peter Lang.

Burnard, L. \& T. McEnery (eds.). (2000). Rethinking Language Pedagogy from a Corpus Perspective: Papers from the Third International Conference on Teaching and Language Corpora. Frankfurt am Main; New York, NY: Peter Lang. 
(ISSN : 2536 - 9555)

Campoy, M. C., Belles-Fortuno, B., Gea-Valor, M. L. (2010). Corpus-Based Approaches to English Language Teaching. Bloomsbury Publishing.

Carter, R. (1998). Linguistic Choice across Genres: Variation in Spoken and Written English. Amsterdam: John Benjamins.

Chambers, A. (2007). 'Popularising Corpus Consultation by Language Learners and Teachers'. In E. Hidalgo, L. Quereda and J. Santana (eds.), Corpora in the Foreign Language Classroom. Amsterdam: Rodopi. pp.3-16.

Conrad, S. (2000). 'Will corpus linguistics revolutionize grammar teaching in the $21^{\text {st }}$ century?' TESOL Quarterly 34, pp. 43860.

EMT expert group. (2017). "Competences for Professional Translators, Experts in Multilingual and Multimedia Communication."

[https://ec.europa.eu/info/sites/info/files/emt_competence_f wk_2017_en_web.pdf]

Flowerdew, L. (2015). "Data-driven Learning and Language Learning Theories." In Leńko-Szymańska and Boulton (eds.), Multiple Affordances of Language Corpora for Datadriven Learning. Amsterdam: Benjamins, pp. 15-36.

Firth, J. R. (1957). 'Modes of meaning'. In: Papers in Linguistics, 1934-1951. Oxford: Oxford University Press.

Francis, W.N. (1982). 'Problems of assembling and computerizing large corpora'. In S. Johansson (ed.), Computer Corpora in English Language Research. Bergen: Norwegian Computing Centre for the Humanities, pp. 7-24.

Gavioli, L. (2000). 'The learner as researcher: introducing corpus concordancing in the classroom' In G. Aston (ed.), Learning with Corpora. Houston, TX: Athelstan/Bologna: CLUEB.

Gavioli, L. (2006). Exploring Corpora for ESP Learning. Amsterdam: John Benjamins. 
A corpus-aided discovery learning (CADL) approach to teaching collocations in TEFL settings

Dr Wesam M. A. Ibrahim \& Dr Amany A. Alsabbagh

مجلة وادي النيل للاراسات والبحوث الإنسانية والاجتماعية والتربوية (مجلة علمية محكمة)

Grabowski, E. and Mindt, D. (1995). 'A corpus-based learning list of irregular verbs in English'. ICAME Journal (19), pp. 522.

Ghadessy, M., Henry, A. and Roseberry, R. L. (eds). (2001). Small Corpus Studies and ELT: Theory and Practice. Amsterdam: John Benjamins.

Granger, S. (1994). 'The learner corpus: a revolution in applied linguistics'. English Today 39(10/3), pp. 25-29.

Granger, S., Hung, J., \& Petch-Tyson, S. (2002). Computer learner corpora, second language acquisition and foreign language teaching. Amsterdam: John Benjamins

Gries, S. (2009). 'What is Corpus Linguistics?' Language and Linguistics Compass (3)5, pp. 1225-1241.

Halliday, M.; Matthiessen, C. (2014). An Introduction to Functional Grammar ( $4^{\text {th }}$ edition). London: Routledge.

Herbst, T. (1996). 'What are collocations: sandy beaches or false teeth?’ English Studies (4), pp.379-393.

Hidalgo, E., L. Quereda \& J. Santana (eds.). (2007). Corpora in the Foreign Language Classroom: Selected Papers from the Sixth International Conference on Teaching and Language Corpora (TALC 6). Amsterdam; New York, NY: Rodopi.

Hunston, S. (2002). Corpora in applied linguistics. Cambridge: Cambridge University Press.

Ibrahim, Wesam. (2013). 'The Healing Power of Food: A corpusbased Study'. Fekr wa Ebdaa فكرو/بداع. College of Women, Ain Shams University.

Ibrahim, Wesam. (2014a). 'Exploring Semantic Domains in the Works of Five Female 19th Century British Novelists: An Assessment of the Effectiveness of WMatrix in Identifying Major Literary Themes'. CDELT Journal (Centre for Developing English Language Teaching). Cairo, Egypt:

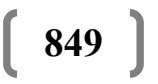


(ISSN : 2536 - 9555)

Faculty of Education, Ain Shams University.

Ibrahim, Wesam. (2014b). 'Representations of Muslim Brotherhood in Egyptian and British Newspapers 20122013: A Synergy of Corpus Linguistics and Critical Discourse Analysis'. CDELT Journal (Centre for Developing English Language Teaching). Cairo, Egypt: Faculty of Education, Ain Shams University.

Johansson, S. (2009). 'Some thoughts on corpora and second language acquisition'. In K. Aijmer (Ed.), Corpora and language teaching. Amsterdam: John Benjamins, pp. 33-44. http://dx.doi.org/10.1075/scl.33.05joh

Johns, T. (1991a). 'Should you be persuaded: Two samples of datadriven learning materials'. ELR Journal 4, pp. 1-16.

Johns, T. (1991b). "From Printout to Handout: Grammar and Vocabulary Teaching in the Context of Data-driven Learning." ELR Journal 4, pp. 27-45.

Kettemann, B. \& G. Marko (eds.). (2002). Teaching and Learning by Doing Corpus Analysis. Proceedings of the Fourth International Conference on Teaching and Language Corpora, Graz 19-24 July, 2000. Amsterdam; New York, NY: Rodopi.

Kettemann, B. and Marko, G. (eds). (2006). Planing, Gluing and Painting Corpora. Inside the Applied Corpus Linguist's Workshop. Frankfurt: Peter Lang.

Kirschner, P. A., J. Sweller, and R. E. Clark. 2006. 'Why minimal guidance during instruction does not work: An analysis of the failure of constructivist, discovery, problem-based, experiential, and inquiry-based teaching'. Educational Psychologist 41 (2), pp 75-86.

Kita, K., and Ogata, H. (1997). 'Collocations in language learning: Corpus-based automatic compilation of collocations and bilingual collocation concordancer'. Computer Assisted Language Learning 10(3), pp.229-238. 
A corpus-aided discovery learning (CADL) approach to teaching collocations in TEFL settings

Dr Wesam M. A. Ibrahim \& Dr Amany A. Alsabbagh

مجلة وادي النيل للاراسات والبحوث الإنسانية والاجتماعية والتربوية (مجلة علمية محكمة)

Krieger, D. (2003). 'Corpus Linguistics: What Is and How Can be Applied to Teaching'. The Internet TESL Journal 9(3).

Krishnamurthy, R. (1996). 'Ethnic, racial and tribal: The language of racism?' In C. R. Caldas- Coulthard \& M. Coulthard (eds.), Texts and practices: Readings in critical discourse analysis. London, England: Routledge, pp. 129-49.

Laviosa, S. (2002). Corpus-based Translation Studies: Theory, Findings, Applications. Amsterdam; New York, NY: Rodopi.

Leech, G. (1992). 'Corpora and theories of linguistic performance'. In J. Svartvik (ed.), Directions in Corpus Linguistics: Proceedings of Nobel Symposium 82. Berlin; New York, NY: Mouton de Gruyter, pp. 105-122.

Leech, G. (1997). 'Teaching and language corpora: A convergence'. In A. Wichmann,S. Fligelstone, T. McEnery, \& G. Knowles (eds.), Teaching and language corpora. London: Longman, pp. 1-23.

Mayer, R. E. (2004). 'Should there be a three-strikes rule against pure discovery learning? The case for guided methods of instruction'. American Psychologist 59 (1), pp. 14-19.

McAlpine, J., and Myles, J. (2003). 'Capturing phraseology in an online dictionary for advanced users of English as a second language: A response to user needs'. System, 31, pp.71-84.

McEnery, T., and Wilson, A. (2001). Corpus linguistics (2nd ed.). Edinburgh: Edinburgh University Press.

McEnery, T., Xiao, R., \& Tono, Y. (2006). Corpus-based language studies: An advanced resource book. London: Roultledge.

Mishan, F. (2005). Designing Authenticity into Language Learning Materials. Bristol: Intellect Books.

Mukherjee, J. (2004). 'Bridging the Gap between Applied Corpus Linguistics and the Reality of English Language Teaching in 
(ISSN : 2536 - 9555)

Germany'. In: U. Connor and T. A. Upton, (eds.), Applied Corpus Linguistics. A Multi-dimensional Perspective. Amsterdam: Rodopi. pp.239-250.

Nunan, D. (1988). The Learner-centred Curriculum. Cambridge: Cambridge University Press.

Nesselhauf, N. (2005). Collocations in a Learner Corpus. Amsterdam: Johns Benjamins.

O'Keeffe, A., McCarthy, M., \& Carter, R. (2007). From corpus to classroom: Language use and language teaching. Cambridge: Cambridge University Press.

Partington, A. (1998). Patterns and Meanings: Using Corpora for English Language Research and Teaching. Amsterdam: John Benjamins.

Römer, U. (2005). Progressives, patterns pedagogy: A corpusdriven approach to English progressive forms, functions, contexts and didactics. Amsterdam: John Benjamins.

Scott, M. (2008). WordSmith Tools version 5. Liverpool: Lexical Analysis Software.

Scott, M., \& Tribble, C. (2006). Textural patterns: Key words and corpus analysis in language education. Amsterdam: John Benjamins.

Semino, E., \& Short, M.H. (2004). Corpus stylistics: speech, writing and thought presentation in a corpus of English writing. London: Routledge.

Schmidt, R. (2010). 'Attention, awareness, and individual differences in language learning'. In W. M. Chan, S. Chi, K. N. Cin, J. Istanto, M. Nagami, J. W. Sew, T. Suthiwan, \& I. Walker, Proceedings of CLaSIC 2010, Singapore, December 2-4. Singapore: National University of Singapore, Centre for Language Studies, pp. 721-737.

Sinclair, J.M. (1987a). Collins COBUILD English Language Dictionary. London: Collins. 
A corpus-aided discovery learning (CADL) approach to teaching collocations in TEFL settings

Dr Wesam M. A. Ibrahim \& Dr Amany A. Alsabbagh

مجلة وادي النيل للاراسات والبحوث الإنسانية والاجتماعية والتربوية (مجلة علمية محكمة)

Sinclair, J. (1987b). 'Collocation: a progress report'. In R. Steele \& T. Threadgold (eds.), Language topics: Essays in honour of Michael Halliday, pp.319-331.

Sinclair, J. (1987c). 'The nature of the evidence'. In J. Sinclair (ed.), Looking up: an account of the COBUILD project in lexical computing and the Development of the COLLINS COBUILD English Language Dictionary. London: Harper Collins, pp. 150-159.

Sinclair, J. (1991). Corpus, concordance, collocation. Oxford: Oxford University Press.

Sinclair, J. (1996). "The Search for Units of Meaning.” Textus 9.1, pp. 75-106.

Sinclair, J.M. (2003). Reading Concordances: An Introduction. London; New York, NY: Longman.

Sinclair, J.M. (ed.) (2004). How to Use Corpora in Language Teaching. Amsterdam; Philadelphia, PA: John Benjamins.

Smadja, F., and McKeown, K. (1990). 'Automatically extracting and representing collocations for language generation'. In B. Berwick (Ed.), Proceedings of the 28th annual meeting of Association for Computational Linguistics. Pittsburgh: University of Pittsburgh. pp. 252-259.

Stubbs, M. (1996). Text and corpus analysis. Oxford: Blackwell.

Teubert, W. (2005). Units of meaning, parallel corpora, and their implications for language teaching. Applied Linguistics: A Multidimensional Perspective.

Teubert, W. (2007). Text, Discourse and Corpora: Theory and Analysis. Continuum.

Tribble, C. (2000). 'Genres, keywords, teaching: Towards a pedagogic account of the language of project proposals'. In L. Burnard \& T. McEnery (eds.), Rethinking language pedagogy from a corpus perspective: Papers from the third 
international conference on Teaching and Language Corpora. Frankfurt am Main: Peter Lang, pp. 75-90.

Tsui, A. B. M. (2005). 'ESL teachers' questions and corpus evidence'. International Journal of Corpus Linguistics 10, pp. 335-356.

Vannestal, M. E. and Lindquist, H. (2007). 'Learning English Grammar with a Corpus: Experimenting with Concordancing in a University Grammar Course'. ReCALL 19(3), pp.329-350.

Wichmann, A., Fligelstone, S., McEnery, T., \& G. Knowles (1997). Teaching and language corpora. New York: Addison Wesley Longman, pp. 51-64.

Wynne, M (ed.). (2005). Developing linguistic corpora: a guide to good practice. Oxford: Oxbow Books. Available from: http://ahds.ac.uk/linguistic-corpora/ 